\title{
Abnormalities in Dynamic Brain Activity Caused by Mild Traumatic Brain Injury Are Partially Rescued by the Cannabinoid Type-2 Receptor Inverse Agonist SMM-189
}

\author{
DPu Liu, ${ }^{1}$ Samuel S. McAfee, ${ }^{1}$ Natalie M. Guley, ${ }^{1}$ Nobel Del Mar, ${ }^{1}$ Wei Bu, ${ }^{1}$ Scott A. Heldt, ${ }^{1}$ Marcia G. \\ Honig, ${ }^{1}$ Bob M. Moore II, ${ }^{2}{ }^{1}$ Anton Reiner, ${ }^{1,3}$ and Detlef H. Heck ${ }^{1}$
}

\section{DOI:http://dx.doi.org/10.1523/ENEURO.0387-16.2017}

${ }^{1}$ Department of Anatomy and Neurobiology, University of Tennessee Health Science Center, Memphis, TN 38163,

${ }^{2}$ Department of Pharmaceutical Sciences, University of Tennessee Health Science Center, Memphis, TN 38163, and

${ }^{3}$ Department of Ophthalmology, University of Tennessee Health Science Center, Memphis, TN 38163

\begin{abstract}
Mild traumatic brain injury (mTBI) can cause severe long-term cognitive and emotional deficits, including impaired memory, depression, and persevering fear, but the neuropathological basis of these deficits is uncertain. As medial prefrontal cortex (mPFC) and hippocampus play important roles in memory and emotion, we used multi-site, multi-electrode recordings of oscillatory neuronal activity in local field potentials (LFPs) in awake, head-fixed mice to determine if the functioning of these regions was abnormal after mTBI, using a closed-skull focal cranial blast model. We evaluated mPFC, hippocampus CA1, and primary somatosensory/visual cortical areas (S1/N1). Although mTBI did not alter the power of oscillations, it did cause increased coherence of $\theta(4-10 \mathrm{~Hz})$ and $\beta(10-30 \mathrm{~Hz})$ oscillations within $\mathrm{mPFC}$ and S1N1, reduced CA1 sharp-wave ripple (SWR)-evoked LFP activity in MPFC, downshifted SWR frequencies in CA1, and enhanced $\theta-\gamma$ phase-amplitude coupling (PAC) within mPFC. These abnormalities might be linked to the impaired memory, depression, and persevering fear seen after mTBI. Treatment with the cannabinoid type-2 (CB2) receptor inverse agonist SMM-189 has been shown to mitigate functional deficits and neuronal injury after mTBI in mice. We found that SMM-189 also reversed most of the observed neurophysiological abnormalities. This neurophysiological rescue is likely to stem from the previously reported reduction in neuron loss and/or the preservation of neuronal function and connectivity resulting from SMM-189 treatment, which appears to stem from the biasing of microglia from the proinflammatory M1 state to the prohealing M2 state by SMM-189.
\end{abstract}

Key words: cannabinoid type 2 receptor; Coherence; mild traumatic brain injury; Neuronal oscillations; Phase amplitude coupling

\section{Significance Statement}

Using a mouse model, we show that mild traumatic brain injury (mTBI) caused significant abnormalities in oscillatory neuronal activity patterns in CA1 of hippocampus and medial prefrontal cortex (mPFC), two structures strongly implicated in cognitive and emotional processes. The cannabinoid type-2 (CB2) receptor specific inverse agonist SMM-189, which has been shown to reverse behavioral deficits and neuronal loss in the present model of $\mathrm{mTBI}$, also rescued most of the electrophysiological deficits. Taken together, our current and previously published studies suggest that use of CB2 receptor inverse agonists such as SMM-189, which appear to act by biasing microglia from the proinflammatory M1 state to the prohealing M2 state, may be a promising therapeutic approach for mTBI. 


\section{Introduction}

Mild traumatic brain injury (mTBI) involving a closedhead injury from a blow, blast, or sudden acceleration/ deceleration event is common in civilian, sports and military settings (Miller, 2011a,b; Weinberger, 2011) and can result in cognitive and emotional deficits (Lundin et al., 2006; Malojcic et al., 2008; Niogi et al., 2008; Bryant et al., 2010; Miller, 2011a,b; Weinberger, 2011; Bazarian et al., 2013). The brain pathology associated with mTBI involves diffuse axonal injury (Browne et al., 2011; Johnson et al., 2013; Heldt et al., 2014), but no obvious foci of neuronal loss or other damage (Bazarian et al., 2013). It thus remains uncertain which brain areas are altered so as to produce these deficits and how $\mathrm{mTBI}$ affects neuronal activity in brain areas linked to cognition and emotion. The cognitive and emotional deficits typically associated with mTBI strongly implicate the medial prefrontal cortex (mPFC) and the hippocampus, as these two structures are of central importance for cognitive and emotional functions (Bahner et al., 2015; Spellman et al., 2015; Sigurdsson and Duvarci, 2016). The role of the mPFC and hippocampus in cognitive and emotional processes is characterized by oscillatory neuronal activity at specific frequencies, which transiently synchronizes the activity of neurons within and between the structures (Rauch et al., 2006; Sierra-Mercado et al., 2006; Covington et al., 2010; Popa et al., 2010; Maroun, 2013; Russo and Nestler, 2013; Bocchio and Capogna, 2014; Mueller et al., 2014; Zelikowsky et al., 2014). $\gamma$ Oscillations $(30-100 \mathrm{~Hz})$ in these structures are thought to be of critical importance to cognitive processing, and they are often observed to be nested within specific phases of lower frequency $\delta(1-3$ $\mathrm{Hz}), \theta(4-7 \mathrm{~Hz})$, and $\alpha$ frequency oscillations $(8-12 \mathrm{~Hz})$ in a phenomenon known as phase-amplitude coupling (PAC). The generation of these functionally relevant patterns of neuronal activity, particularly of oscillations that exhibit coherence between regions and coupling of oscillatory frequencies within a local network of neurons, requires the integrity of network connections and synaptic communication (Buzsáki et al., 2013). Thus, coherence and

Received December 29, 2016; accepted July 3, 2017; First published July 24, 2017.

The authors declare no competing financial interests.

Author contributions: D.H.H. and A.R. designed research; N.M.G., N.D.M., W.B., Y.L., and B.M.M. performed research; Y.L., S.S.M., and D.H.H. analyzed data; D.H.H., Y.L., A.R., M.G.H., B.M.M., N.M.G., S.A.H., and S.S.M. wrote the paper.

This work was supported by funding from the University of Tennessee Health Science Center (UTHSC) Department of Anatomy and Neurobiology, the UTHSC Neuroscience Institute and National Institutes of Health (NIH) Grant NS091752 (to D.H.H.), The Office of the Dean of the College of Medicine at UTHSC (A.R.), The Methodist Hospitals Endowed Professorship in Neuroscience (A.R.), the NIH Grant NS-081370 (to A.R.), and the College of Pharmacy at UTHSC (B.M.M.).

Correspondence should be addressed to Dr. Detlef H. Heck, Department of Anatomy and Neurobiology, University of Tennessee Health Science Center, Memphis, TN 38163, E-mail: dheck@uthsc.edu.

DOl:http://dx.doi.org/10.1523/ENEURO.0387-16.2017

Copyright $\odot 2017$ Liu et al.

This is an open-access article distributed under the terms of the Creative Commons Attribution 4.0 International license, which permits unrestricted use, distribution and reproduction in any medium provided that the original work is properly attributed.
PAC of oscillatory neuronal activity reflect functional connectivity patterns in larger neuronal networks (Antonakakis et al., 2015). Coherence analyses of MEG and EEG signals in patients have shown that TBI in humans causes deficits in functional connectivity between brain areas (Varotto et al., 2014; Dimitriadis et al., 2015). We analyzed coherence and PAC of oscillations in hippocampal CA1 region (CA1) and mPFC in a mouse model of $\mathrm{mTBI}$ to evaluate the whether mTBI would cause similar electrophysiological abnormalities in these areas. We also characterized hippocampal sharp wave ripples and their effect on mPFC local field potential (LFP) responses to further quantify deficits in oscillatory neuronal activity and functional connectivity. Hippocampal sharp-wave ripples (SWRs) have been suggested as a mechanism to redistribute newly encoded memories from the hippocampus to the neocortex (Wierzynski et al., 2009).

The focal cranial air blast model of mTBI used here mimics closed-skull impact, the most common type of TBI (Heldt et al., 2014; Reiner et al., 2014; Guley et al., 2016). The model is characterized by diffuse axonal injury, microglial activation, and a variety of sensory, motor, cognitive, and emotional deficits. In particular, the memory deficits include defective working memory out to eight months post-blast as assessed by spontaneous alternation in an X-maze (our unpublished observations), depression as assessed by tail suspension (Heldt et al., 2014; Reiner et al., 2014), and heightened learned fearfulness as assessed using auditory fear conditioning (Heldt et al., 2014; Reiner et al., 2014).

We performed all electrophysiological measurements in awake, head fixed mice (Bryant et al., 2009), and observed a variety of abnormalities after mTBI. Additionally, we assessed whether the cannabinoid type-2 (CB2) receptor inverse agonist SMM-189 (Presley et al., 2015) rescued any of the $\mathrm{mTBI}$-related abnormalities in oscillatory neuronal activity, coherence and PAC in the mPFC and hippocampus. We chose SMM-189 because previous studies with the same mouse model have shown that the drug rescued mTBI-related neurologic deficits, including depression and fear perseveration reduced neuron loss caused by mTBI (Reiner et al., 2014; Bu et al., 2016).

\section{Materials and Methods}

\section{Animal care}

Thirty-seven adult (more than three to four months) male mice (C57BL/6J) were used in the present study. Mice were housed within a breeding colony at the University of Tennessee Health Science Center animal facilities with 12/12 h light/dark cycles in standard cages with free access to food and water. All animal procedures were performed in accordance with the National Institutes of Health Guide for the Care and Use of Laboratory Animals (2011). Experimental protocols were approved by the University of Tennessee Health Science Center Institutional Animal Care and Use Committee.

\section{Summary of time course of experimental procedures}

(1) Adult mice between three and four months of age received controlled left side air blasts to the closed skull 
to induce $\mathrm{mTBI}$ or received sham treatment as described in (Heldt et al., 2014; Guley et al., 2016).

(2) Beginning at $2 \mathrm{~h}$ following the blast or sham treatment, mice received daily injections for two weeks of either drug (SMM-189) or vehicle as described previously (Reiner et al., 2014).

(3) Four to five weeks after the blast or sham treatment, electrophysiological recordings were performed in mPFC, CA1 and S1/N1 in awake, head fixed conditions as described below.

(4) After completion of experiments, recording sites were verified histologically.

\section{Mild TBI induction and drug/vehicle treatments}

In the first experiment, mice were randomly divided into the sham-vehicle (vehicle-treatment only), mTBI-vehicle (blast + vehicle) and mTBI-drug (blast + SMM-189) groups (nine mice in each group). In a second set of experiments, we evaluated the effect of SMM-189 on a separate group of 10 sham-treated mice, randomly assigned to receive SMM-189 or vehicle treatment (five mice in each group).

Mild TBI was induced by a focal closed-head air blast of 50 -psi to the left side of the head. Sham-treated mice underwent the same procedures but did not receive an air blast. SMM-189 was administered daily $(6 \mathrm{mg} / \mathrm{kg}$ injected i.p., dissolved in vehicle; ethanol:cremophor:0.9\% saline; 5:5:90; between 0.1 and $0.2 \mathrm{ml}$, depending on body weight). The first injection was administered within $2 \mathrm{~h}$ after mTBI or sham treatment. This mTBI model was developed and validated by Reiner and colleagues (Heldt et al., 2014; Guley et al., 2016), who have also evaluated the efficacy of SMM-189 in this model (Reiner et al., 2014; Bu et al., 2015). We used a blast pressure level of 50-psi, which produces widespread axonal injury and microglial inflammation with minimal mortality (Heldt et al., 2014; Reiner et al., 2014; Guley et al., 2016). Briefly, the overpressure air blast was delivered by a small horizontally mounted air cannon system. Mice were anesthetized with Avertin (400 mg/kg body weight) and secured within a foam rubber sleeve inside a pair of Plexiglas tubes with their targeted head region positioned in the center of a 7.5- $\mathrm{mm}$ diameter hole in the outer tube and the air cannon opening positioned $4-5 \mathrm{~mm}$ from the hole in the outer tube. This arrangement restricted the blast exposure to a 7.5- $\mathrm{mm}$ diameter area on the left side of the mouse cranium between ear and eye. The rest of the mouse was completely shielded from the blast by the Plexiglas tubes. The foam rubber sleeve surrounding the mouse cushioned the nonblast side of the mouse. Afterward, animals recovered on a heating pad. Tylenol $(35 \mathrm{mg} / \mathrm{ml})$ was added to the drinking water for $24 \mathrm{~h}$ following blast exposure for sham and blast-treated mice.

\section{Choice of air pressure parameters for mild TBI induction}

Previous studies using the same mouse model for mTBI we employed here evaluated the effects of air blast pressures ranging from 0-psi (sham) to 60-psi on three-monthold male C57BL/6 mice (Heldt et al., 2014; Reiner et al., 2014; Bu et al., 2016; Guley et al., 2016). Those studies found that mice subjected to single blasts of 40-psi or less showed no significant motor or behavioral deficits in tests for depression and fear learning and little obvious neuronal damage or axonal injury. By contrast, histologic analysis of mice subjected to a single blast of 50-60 psi revealed axonal injury, neuronal loss, and microglial activation in a variety of brain regions (Heldt et al., 2014; Bu et al., 2016; Guley et al., 2016). These mice were reported to also demonstrate a variety of deficits during the first few months after blast, and most notably for present interest, memory loss (our unpublished observations), increased depression and fear perseveration (Heldt et al., 2014; Guley et al., 2016). To further explore the basis of the deficits with 50- to 60-psi blasts, here we used a blast pressure of 50-psi to examine the effects of mTBI on neuronal activity in $\mathrm{mPFC}, \mathrm{S} 1 \mathrm{~N} 1$ and $\mathrm{CA} 1$, because of the deficits it yields with minimal mortality. We found that mice exposed to 50-psi focal closed-head cranial blasts to the left side of the head showed a variety of deficits in neuronal activity patterns in the left MPFC and hippocampal CA1, which are likely to be contributory to the previously reported behavioral deficits, especially those concerning memory, fearfulness, and mood.

\section{Treatment groups}

In a first set of experiments, we used a 50-psi blast to induce $\mathrm{mTBI}$ in two groups of nine mice each. A third group of nine mice in the first set of experiments received sham treatment, i.e., they were exposed to identical procedures with the exception that no air blast was delivered to the cranium. Mice exposed to mTBI-producing blasts were randomly assigned to either an mTBI-vehicle (blast + vehicle) or an mTBI-drug (blast + SMM-189 treatment) group. Sham-treated mice from this group received vehicle injections only.

A separate group of 10 mice was used to investigate the effects of SMM-189 versus vehicle treatment on sham-treated mice. Mice were randomly divided into two groups of 5 mice each which received either daily injections of SMM-189 or vehicle, following the same treatment schedules and procedures used for the first set of experiments.

Because SMM-189 is not soluble in water, it was dissolved in a $0.9 \%$ saline vehicle solution containing ethanol and cremophor (90:5:5), both of which are regarded as safe for human use by the Food and Drug Administration. After the completion of vehicle or drug treatment, mice were housed for two more weeks before electrophysiological recordings started.

\section{Surgery}

Four to five weeks after blast or sham treatments, mice were surgically prepared for awake, head fixed, electrophysiological recordings. Surgical anesthesia was initiated by exposing mice to a mix of $3 \%$ isoflurane in oxygen in an incubation chamber. Anesthesia was maintained with $1-2 \%$ isoflurane in oxygen during surgery using an Ohio isoflurane vaporizer (Highland Medical Equipment). Rectal temperature was maintained at $37-38^{\circ} \mathrm{C}$ with a servo-controlled heat blanket (FHC). To prepare for electrophysiological recordings from the blasted side of the 
A

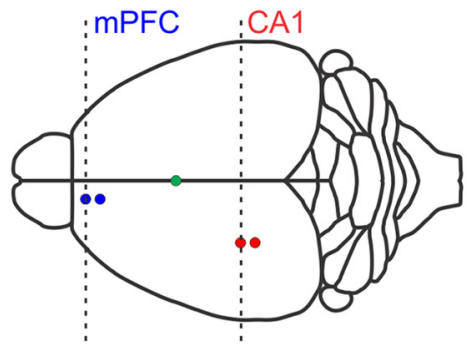

B

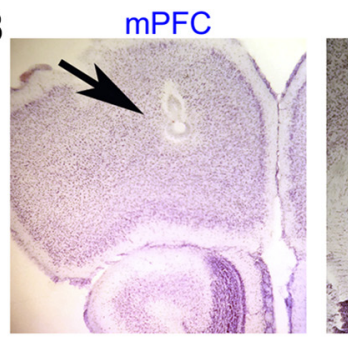

CA1

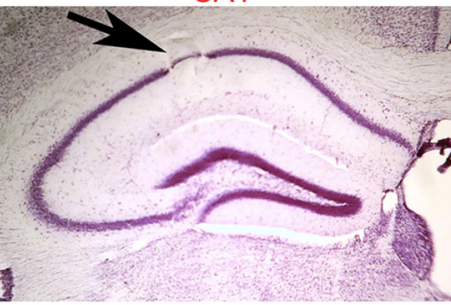

C $\mid \begin{aligned} & 600 \mu \mathrm{V}(\text { LFP1, 2) } \\ & 1200 \mu \mathrm{V}(\mathrm{LFP} 3,4)\end{aligned}$
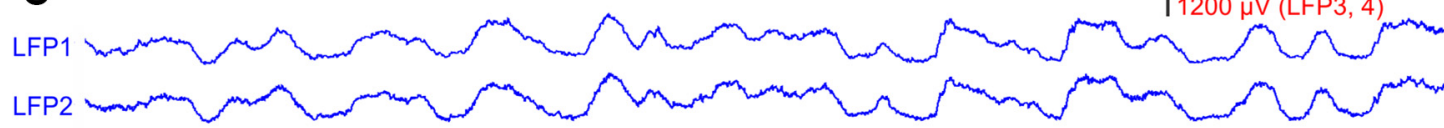

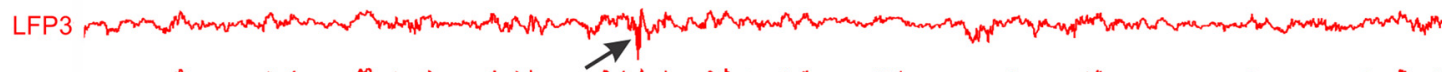

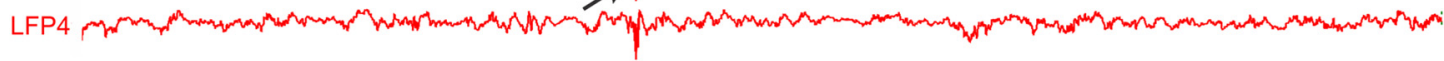
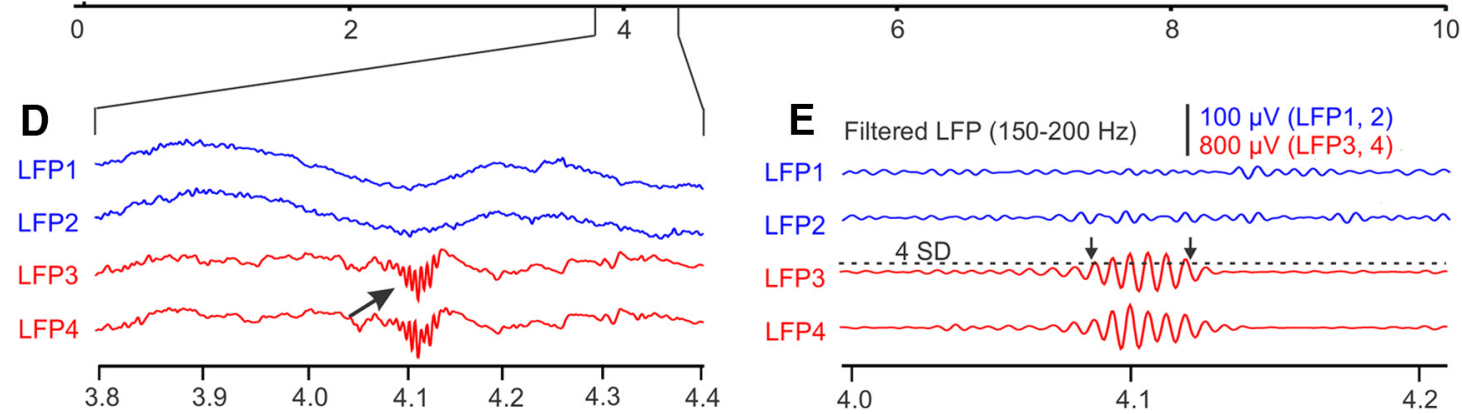

Figure 1. Recording sites and raw data examples of simultaneous recordings of LFPs in the awake mouse mPFC and hippocampal CA1 region. $\boldsymbol{A}$, Schematic drawing of the top view of a mouse brain. LFPs were simultaneously recorded from the left PFC along the boundary between the frontal association area and prelimbic cortex (blue dots) and S1/N1 transition area (red dots). The electrodes in S1/V1 (red dots) were advanced into the CA1 region of the hippocampus following recording in S1/N1. The green dot represents bregma. Dashed lines represent the coronal sections for verifying recording locations in the mPFC and CA1 in a mouse not included in this study but recorded following identical procedures (see Materials and Methods). B, Electrolytic lesions (arrows) in the mPFC (left) and the CA1 region of hippocampus (right) marking sites from which recordings shown in $\boldsymbol{C}$ were obtained. $\boldsymbol{C}$, Examples of raw LFP data recorded at sites indicated in $\boldsymbol{A}$. LFP1 and LFP2 were recorded from electrodes positioned in the mPFC (blue); LFP3 and LFP4 were recorded from electrodes in the CA1 (red). Arrow points at a characteristic high-frequency ripple activity. Abscissa represents time in seconds. $\boldsymbol{D}$, An enlarged view of raw LFPs around a hippocampal ripple event (arrow). Same LFP amplitude scale bar as in $\boldsymbol{C}$. $\boldsymbol{E}$, High-pass filtered versions of the LFPs in panel $\boldsymbol{D}$ emphasizes the high-frequency ripple components of CA1 activity. Horizontal dashed line above LFP3 represents the mean filtered LFP amplitude plus 4 SD from a continuous data of $60 \mathrm{~s}$, which was used as a threshold (mean $\pm 4 \mathrm{SD}$ ) for automatic detection of SWR activity in the CA1 region. Left and right arrows mark the beginning and the end of ripple activity, respectively.

brain, two round skull openings (1.0-1.5 $\mathrm{mm}$ in diameter) over the left mPFC and the left hippocampus were made using a dental drill (Microtorque II, RAM Products) without damaging the underlying dura (Fig. 1A). Stereotaxic coordinates for the center of the medial prefrontal cortical target area were $0.5 \mathrm{~mm}$ lateral to midline and $2.8 \mathrm{~mm}$ anterior to bregma. For the hippocampal CA1 target region, coordinates were $2.0 \mathrm{~mm}$ lateral to midline and 2.3 $\mathrm{mm}$ posterior to bregma. A cylindrical plastic recording chamber (0.45-cm diameter and 8-mm height) was placed over the skull openings and a metal head-post was mounted on the skull for head fixation during experiments. The chamber and head-post were embedded in acrylic cement and anchored to the skull bone using three small skull screws. The chamber was completely filled with triple antibiotic ointment. While still under anesthesia, mice were injected subcutaneously with Carprofen solution $(0.05 \mathrm{ml} ; 50 \mathrm{mg} / \mathrm{ml})$ to alleviate pain. A postsurgical recovery period of 3-4 d was allowed before electrophysiological experiments.

\section{Electrophysiological experiments}

Mice were adapted to the head-fixed position by placing them in the head holder for increasing amounts of time before the first recording session. We recorded from each mouse up to three times but only once per day. Before each recording session, the chambers were cleaned and filled with saline solution. Four extracellular recording electrodes (glass insulated tungsten/platinum; $80 \mu \mathrm{m}$ in diameter; impedance: 3.5-5.0 $\mathrm{M} \Omega$ ) were used to record LFPs. During experiments, the guiding tubes of a computer-controlled microdrive (Thomas Recording) were lowered into the saline-filled recording chamber to a distance of $<1 \mathrm{~mm}$ from the dural surface. In the Thomas Recording System, the guiding tubes also serve as reference electrodes and their electrical connection to the 
brain tissue is established via the saline solution. Two recording electrodes ( $80 \mu \mathrm{m}$ in diameter, $350 \mu \mathrm{m}$ apart) were slowly advanced through the intact dura into the mPFC along the border between the frontal association area and the prelimbic cortex. A second pair of electrodes was advanced into the neocortex directly overlying the hippocampal CA1 region, which is an area that lies at the caudal boundary of the primary somatosensory cortex (S1) and the rostral boundary of the primary visual cortex (V1), and which we thus refer to as S1/V1. After recording from the S1/N1 region of neocortex, the electrodes were lowered into the CA1 proper for subsequent recordings. Statistical comparisons of coherence results from the rostral S1 and caudal V1 recordings sites revealed no significant differences. Therefore, we pooled all data recorded at S1/V1 sites. Since this study focused on alterations in LFP activity, no effort was made to isolate single unit spike activity. The accuracy of electrode penetrations was verified postmortem for all animals by reference to surface maps of the location of cortical areas and hippocampus (Paxinos and Franklin, 2001; Mohajerani et al., 2013). During the recordings from CA1, penetration depth and the occurrence of characteristic SWRs in the LFP signal were used to verify the localization of the electrode tip in the CA1 region (Buzsáki, 2015; Fig. 1C-E). Recording depth in the MPFC was estimated based on anatomically confirmed recording sites from recordings in $>10$ mice that were performed before and were not related to this study. No lesions were made in blast-treated mice included in this study, to minimize tissue damage, which could interfere with subsequent immunohistochemical analysis, which is not part of the current study. However, the depth of electrode placement was again verified for all recordings from sham-treated mice and showed successful placement of electrode tips in the MPFC using the same procedures as for the blast-treated mice. An example of electrolytic lesions marking the recording sites in the mPFC and CA1 is shown in (Fig. 1B).

Simultaneous recordings of LFPs from the MPFC and S1/V1 or from the mPFC and hippocampal CA1, with two electrodes placed within each structure, were used to evaluate both the within-structure and the betweenstructure coherence of LFP oscillations and of an mPFCCA1 interaction in the form of CA1-SWR evoked LFPresponses in the MPFC. All signals were bandpass filtered at $0.1-200 \mathrm{~Hz}$, digitized at $2 \mathrm{kHz}$ and saved to a hard-disk (CED 1401 and Spike2 software, Cambridge Electronic Design).

\section{Data analysis}

\section{LFP coherence}

Coherence was calculated for LFP signals recorded at two recording sites within the mPFC, S1/V1 or CA1. We calculated coherence both between the electrodes in a given structure, as well as coherence between structures. For between-structure coherence, we used the more anteriorly located electrodes in each structure for consistency. Recordings consisted of continuous 10-min samples of LFP activity. From the 10-min recordings, five 1-min periods without movement artifacts were selected and exported from Spike2 to a Matlab (Mathworks) file format. Coherence analysis was performed in Matlab (Matlab, R2015a) using custom scripts (Matlab function code: mscohere).

\section{Detection of SWR activity in the CA1}

For the analysis of hippocampal SWRs, raw LFPs were bandpass filtered at the frequency range known to contain of SWR frequencies (Sullivan et al., 2011; Schlingloff et al., 2014; 150-200 Hz; Fig. 1E). The mean amplitude and SD of LFP amplitude fluctuation across each $1 \mathrm{~min}$ data block were calculated from the band passed signal. Potential SWR onsets were detected as LFP values larger or smaller than the average LFP value by \pm 4 SDs. A minimum of five-ripple waveforms (defined as five equidistant voltage peaks) was required for the detected potential SWR onset to qualify as a true SWR. The end of an SWR was marked as the first LFP voltage that fell within the \pm 4 SDs voltage range around the mean LFP, with the following voltage values remaining within this range for $100 \mathrm{~ms}$. Based on this criterion, we treated SWRs separated by at least $100 \mathrm{~ms}$ as two distinct SWR events.

\section{Time-frequency analysis of SWRs}

To examine time-frequency aspects of SWR activity in the CA1 region of the hippocampus, LFPs were analyzed using an open-source software FieldTrip (Oostenveld et al., 2011). Sections of LFP data from $0.6 \mathrm{~s}$ before and $0.6 \mathrm{~s}$ after SWR onsets were selected for the performance of SWR-aligned time-frequency analysis (FieldTrip function: ft_freqanalysis; method: mtmconvol; tapper: hanning; window size: $0.2 \mathrm{~s}$; step: $1 \mathrm{~ms}$; sample rate: 2000 $\mathrm{Hz}$; frequency rang: $100-220 \mathrm{~Hz}$ ).

\section{$P A C$ analysis of LFP}

The same sections of LFP data in MPFC and CA1 used for coherence analysis were also selected for PAC analysis. In particular, the relationships between the phases of LFP oscillations in the $\delta, \theta$, and $\alpha$ frequency range (1-12 $\mathrm{Hz}$ ) and the amplitudes of oscillations in the $\gamma$ frequency range $(30-100 \mathrm{~Hz})$ were evaluated and then compared between groups. The PAC of LFP oscillations was quantified using an open-source Matlab Toolbox written by Angela Onslow (www.cs.bris.ac.uk/Research/MachineLearning/pac), documented previously (Bruns and Eckhorn 2004; Canolty et al., 2006; Osipova et al., 2008; Onslow et al., 2011). Values corresponding to the degree of PAC (i.e., modulation index indicating the extent to which low-frequency phase is related to high-frequency amplitude) were normalized before averaging or grouping within conditions.

\section{Statistical analyses}

One-way ANOVA in MATLAB Statistics Toolbox (code: anova1) was used to analyze changes in LFP activities between experimental groups (code: multcompare; post hoc test: Tukey-Kramer). Unless specified otherwise, figures represent results as mean $\pm \mathrm{SE}$.

\section{Histology}

In sham-treated mice, an electrolytic lesion in mPFC and/or CA1 was made by passing an electrical current (10 $\mu \mathrm{A} ; 12 \mathrm{~s})$ through one of the recording electrodes. Lesions 
were made at the end of the final experiments, and no electrolytic lesions were made in the S1/V1 region. All animals were deeply anesthetized and intracardially perfused with $0.9 \% \mathrm{NaCl}$ and followed by $4 \%$ paraformaldehyde solution. Brains were removed and fixed in $4 \%$ paraformaldehyde solution for a minimum of $24 \mathrm{~h}$. The accuracy of electrode penetrations was verified postmortem for all animals by reference to surface maps of the location of cortical areas and hippocampus (Paxinos and Franklin, 2001; Mohajerani et al., 2013). For animals with electrolytic lesions, the fixed brains were sectioned at 60 $\mu \mathrm{m}$ and mounted onto slides. Light microscopy was used to verify the accurate depth of penetration of the recording electrode in the PFC and the CA1 region of the hippocampus (Fig. 1B).

\section{Results}

\section{Resting-state coherence of LFP oscillation within} mPFC, S1/V1, and hippocampal CA1 region

Four to five weeks after left side 50-psi or sham blast, LFP recordings were obtained from sites within the left mPFC, hippocampal CA1 region or the S1/V1 cortex (Fig. 1). Analysis of the oscillation power spectra for each brain region revealed no significant differences between treatment groups (one-way ANOVA; data not shown). Mild TBI did, however, cause a significant elevation of LFP oscillation coupling (coherence) across the two mPFC recording sites, significantly so in the low $(1-30 \mathrm{~Hz})$ and high $(150-200 \mathrm{~Hz})$ frequency oscillation ranges in mTBI vehicletreated mice (Fig. 2A), compared to the sham vehicletreated mice. A similar pattern of elevated coherence was observed across the two recording electrodes in S1/V1 in mTBI mice compared to the sham vehicle-treated mice, but only the elevation in the low-frequency coherence (1-30 Hz) reached statistical significance (Fig. 2B). Mild TBI caused no changes in LFP coherence in CA1 (Fig. 2C). Treatment with SMM-189 normalized LFP coherence in the mPFC (Fig. 2A) but not in S1/N1 (Fig. 2B). SMM-189 treatment had no effect on within-CA1 LFP coherence compared to the sham vehicle-treated mice (Fig. 2C), neither increasing nor lowering it.

\section{Resting-state coherence of LFP oscillation between MPFC and S1/V1 and between MPFC and CA1}

Coherence of oscillatory LFP activity between mPFC and S1/V1 or between MPFC and CA1 was not significantly altered by mTBI. There was also no significant effect of drug treatment on between-region coherence (one-way ANOVA used for both analyses; data not shown).

\section{Frequency and power of SWR activity in CA1}

We asked whether mTBI affected the peak frequency or power of the rapid oscillations characterizing the SWRs in CA1 and whether SMM-189 treatment would normalize any such potential change in SWR activity. Time-frequency analysis of SWR oscillations revealed a significant drop in the peak SWR oscillation frequency to $\sim 145 \mathrm{~Hz}$ in 50 -psi blast vehicle-treated compared to $\sim 155 \mathrm{~Hz}$ in sham blast vehicle-treated mice (Fig. $3 A, B$ ). The SWR
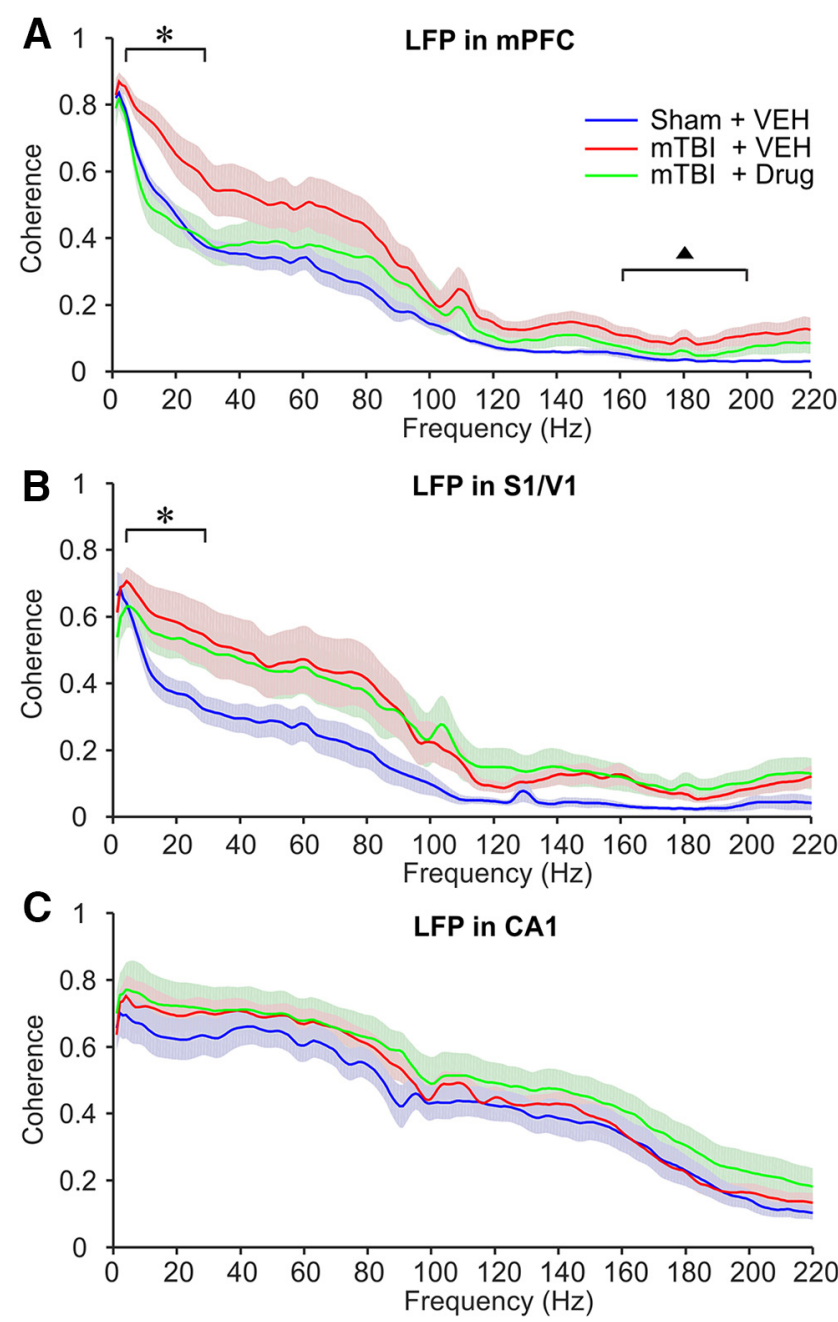

Figure 2. Coherence in the LFP oscillation in mice with mTBI. $\boldsymbol{A}$ mPFC. $* F_{(2,24)}=5.2474, p=0.0129$; sham + VEH versus $\mathrm{mTBI}$ + VEH: $p=0.0499 .{ }^{\wedge} F_{(2,24)}=3.4297, p=0.0490$; sham + VEH versus $\mathrm{mTBI}+\mathrm{VEH}: p=0.0411 . \boldsymbol{B}, \mathrm{S} 1 \mathrm{~V} 1 . * F_{(2,24)}=4.1190, p$ $=0.0337$; sham + VEH versus $\mathrm{mTBI}+\mathrm{VEH}: p=0.0326$. $\boldsymbol{C}$, Hippocampal CA1 region. The same color codes are used for all panels. Data were expressed as mean \pm SE. Comparisons of mean coherence between 4 and $30 \mathrm{~Hz}$ were conducted using one-way ANOVA (post hoc test: Tukey-Kramer). VEH, vehicle.

peak frequency in 50-psi blast drug-treated mice, by contrast, was statistically no different from in sham blast vehicle-treated mice, suggesting that SMM-189 treatment rescued SWR peak frequency after mTBI (Fig. $3 A, B$ ). There were no significant differences in the relative power of oscillatory activity within the ripple-frequency band (150-200 Hz) among the three groups, i.e., the amplitude of the SWRs was not affected by mTBI or SMM-189 treatment (Fig. 3C).

\section{Change in SWR-associated LFP}

Although the coherence of oscillations between CA1 and MPFC was not altered by mild TBI, analysis of SWRs showed that TBI did affect communication between these two regions. Hippocampal SWRs have been shown to alter neuronal activity in the PFC, and this modulation has 

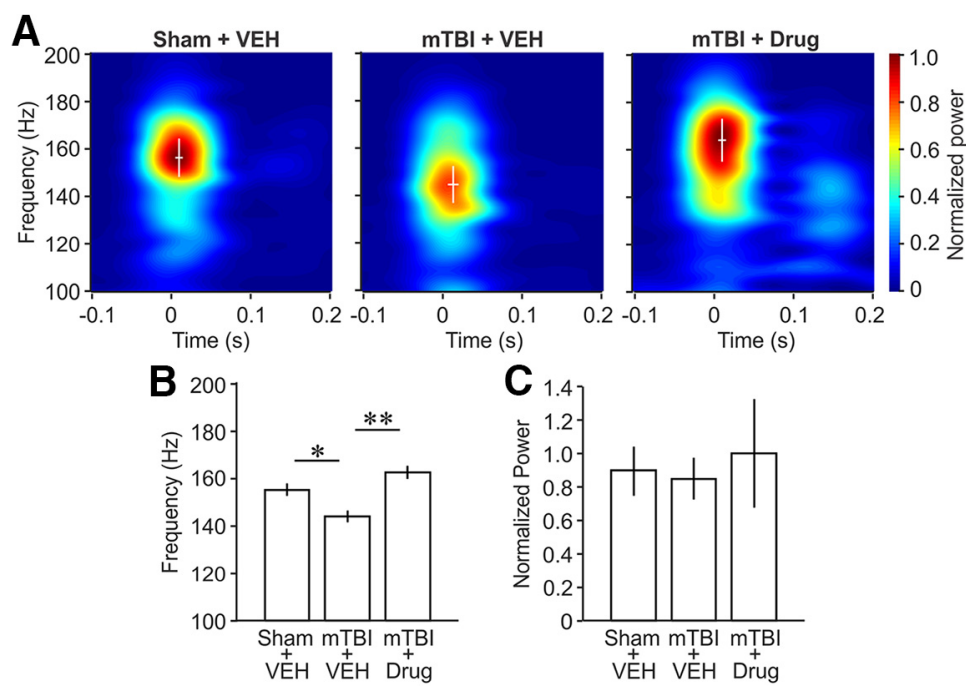

Figure 3. Time-frequency analysis of ripple activity in the hippocampal CA1 region. $\boldsymbol{A}$, Time-frequency mapping of LFP around CA1 ripples. Data are aligned on the onset of ripple activity (at time $0 \mathrm{~s}$ ). Color represents frequency power normalized to the maximal power in the three groups. The white cross that is centered at the peak-frequency-power represents mean \pm SD of the peak-power times (abscissa) and peak frequencies (ordinate) of ripple activities. $\boldsymbol{B}, \boldsymbol{C}$, Comparisons of peak frequency $\boldsymbol{B}$ and frequency power of ripple activity $\boldsymbol{C}$. Data are expressed as mean \pm SE. One-way ANOVA (post hoc test: Tukey-Kramer) for peak frequency in $\boldsymbol{B}$ : $F_{(2,24)}$ $=12.6401, p=0.0463 ; * p=0.0159 ; * * p=0.0001$. VEH, vehicle.

been implicated in the transfer of memory content from hippocampal to cortical storage (Wierzynski et al., 2009). We examined the effect of mTBI on MPFC responses to the occurrence of spontaneous SWRs in CA1 by analyzing the average LFP response in the MPFC aligned on SWR onset (Fig. 4). In the sham blast group, SWRs in CA1 evoked a positive LFP deflection in the MPFC, which reached its peak amplitude around $50 \mathrm{~ms}$ after SWR onset. The SWR-evoked response in the MPFC was significantly reduced in mTBI-vehicle-treated mice, and treatment of $\mathrm{mTBI}$ mice with SMM-189 rescued the MPFC response to CA1 SWRs (Fig. 4A). The average amplitude of SWRs in CA1 was itself, however, not altered in mTBIvehicle treated compared to sham-treated mice (as noted above). However, mTBI drug-treated mice showed a significant SWR amplitude increase in CA1 during the late positive phase of the SWR (Fig. 4B). This late-phase increase in amplitude was also reflected in time-frequency analysis in the form of a temporary increase in power in the 5- to $10-\mathrm{Hz}$ range (data not shown).

LFP oscillation PAC of $\delta / \theta / \alpha$ phase with $\gamma$ amplitude

PAC is a phenomenon in which the amplitude of $\gamma$ band oscillations increases selectively during a specific phase of a simultaneously occurring slower oscillation. Crossfrequency PAC has been observed in multiple brain structures, including the mPFC and CA1 (Li et al., 2012; Ito et al., 2013; Lisman and Jensen, 2013; Vaidya and Johnston, 2013; Roux and Uhlhaas, 2014), and has been implicated in cognitive processes such as context-dependent reward learning (Tort et al., 2009). We performed a PAC analysis separately for the amplitude of low (30-55 $\mathrm{Hz})$ and high $(55-100 \mathrm{~Hz}) \gamma$ frequency ranges relative to the phases of frequencies in the $\delta, \theta$, and $\alpha$ range (1-12 $\mathrm{Hz}$ ). In the mPFC of 50-psi blast mice that received vehicle injections, $\theta$ to $\gamma$ PAC was significantly increased for both low and high $\gamma$ frequencies, compared to sham mice (Fig. 5A,C). By contrast, in CA1 PAC between $\theta(\sim 5-8 \mathrm{~Hz})$ and $\gamma$ was similar in blast and sham mice (Fig. 5B,D). Following drug treatment, neither mPFC nor CA1 PAC
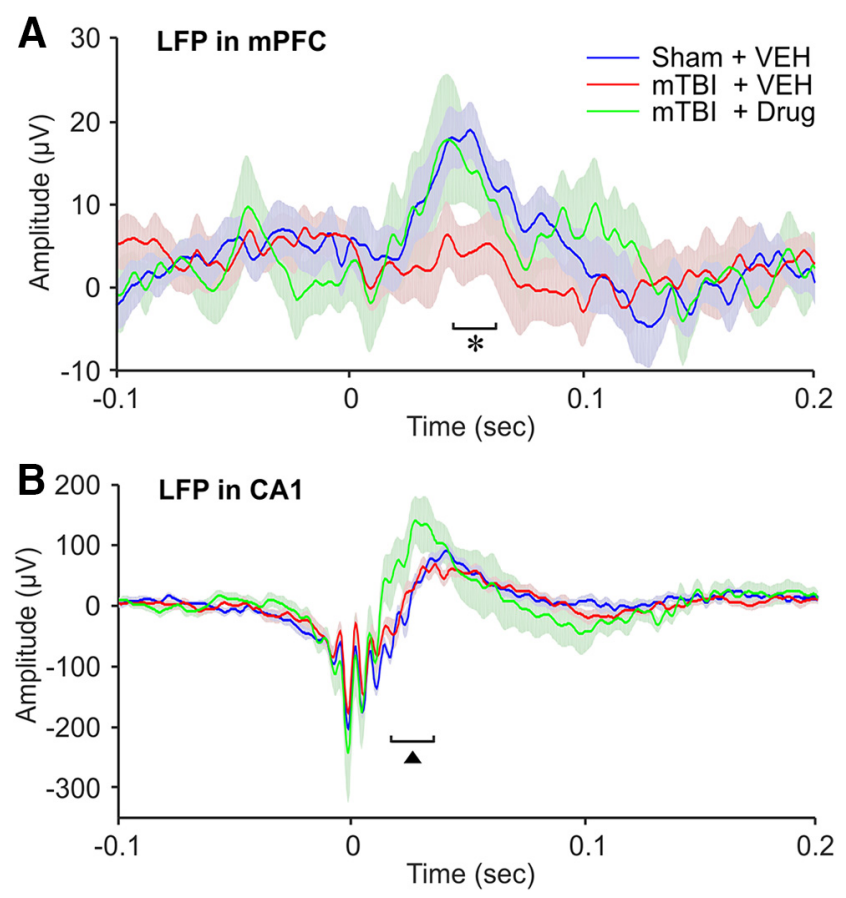

Figure 4. Changes in the amplitude of LFP in the mPFC during hippocampal ripple activities. $\boldsymbol{A}, \boldsymbol{B}$, LFPs recorded in the mPFC and hippocampal CA1 region, respectively. Data are aligned on the onset of the hippocampal ripples $(t=0 \mathrm{~s})$. One-way ANOVA (post hoc test: Tukey-Kramer): $* F_{(2,24)}=3.5031, p=0.0463$; sham + VEH versus mTBI + VEH: $p=0.0456 .{ }^{\wedge} F_{(2,24)}=4.0177$, $p=0.0313$; sham + VEH versus $\mathrm{mTBI}+$ drug: $p=0.0489$. VEH, vehicle. 
A mPFC $_{\text {Sham }+V E H}$

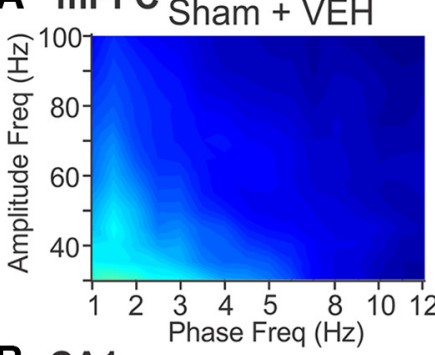

B CA1

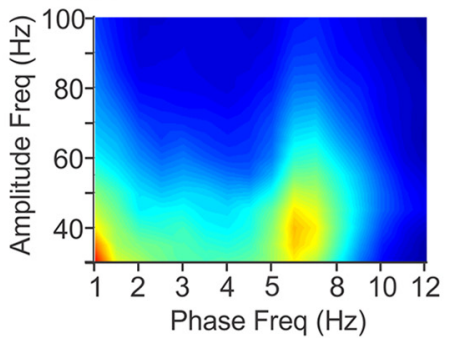

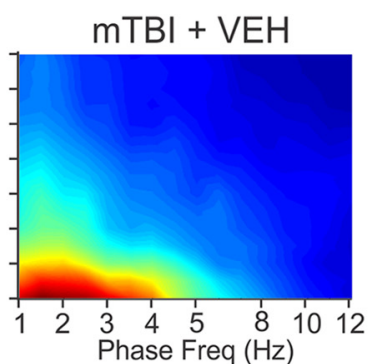

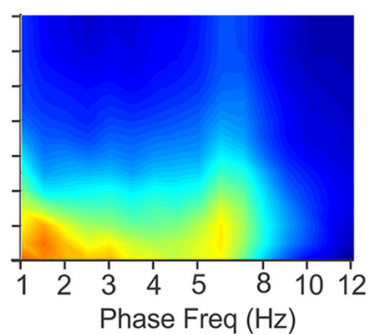

mTBI + Drug
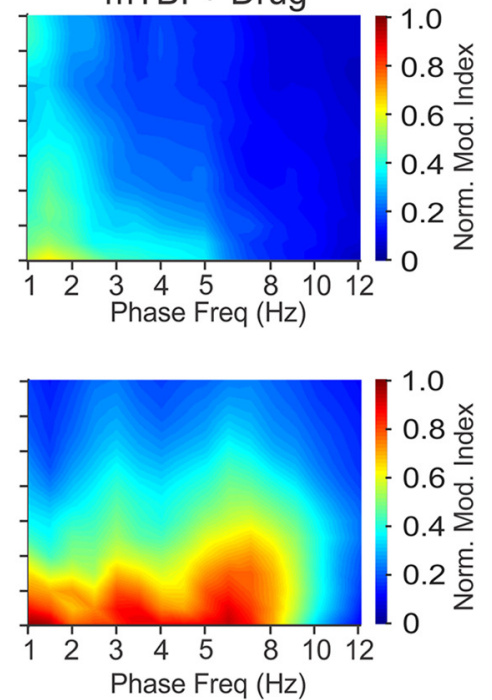

\section{C $\mathrm{MPFC}$}

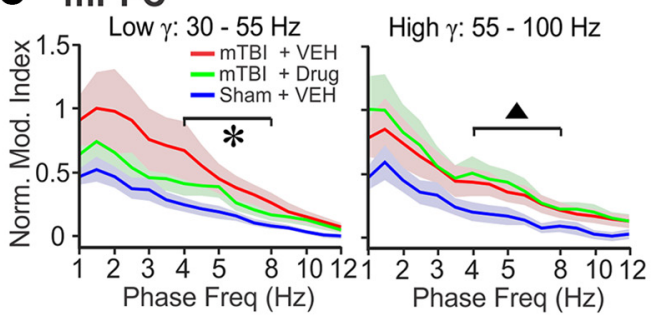

D CA1

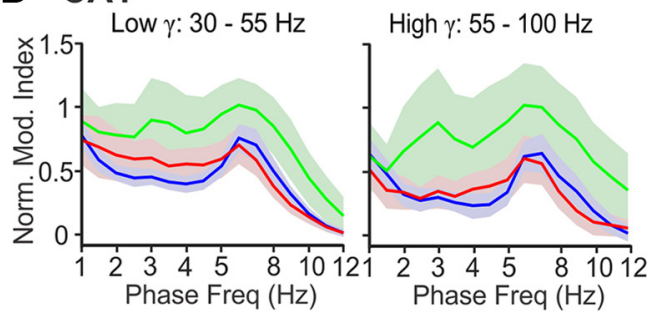

Figure 5. $\theta$ Oscillatory phase modulates $\gamma$-band LFP activity in mice with mTBI. $\boldsymbol{A}$, PAC mapping of LFP activity in the mPFC. PAC values (color-coded) are normalized to the maximum value found within the three experimental groups within each region. $\boldsymbol{B}$, PAC mapping of LFP activity in CA1. The same method for data-normalization as in $\boldsymbol{A}$ was used. $\boldsymbol{C}$, Line-graph representations of PAC in the mPFC for each experimental condition, shown separately for the low $\gamma$ (low $\gamma$, left panel) and high $\gamma$ (high $\gamma$, right panel) frequency ranges. Data are expressed as mean \pm SE. One-way ANOVA (post hoc test: Tukey-Kramer): $* F_{(2,24)}=2.8977, p=0.0746$; sham + VEH versus $\mathrm{mTBI}+\mathrm{VEH}: p=0.0604 .{ }^{\wedge} F_{(2,24)}=3.0115, p=0.0681$; sham $+\mathrm{VEH}$ versus $\mathrm{mTBI}+$ drug: $p=0.0759 . \boldsymbol{D}$, Same analysis as in panel $\boldsymbol{C}$ but for the hippocampal CA1 region. Same data legends as in $\boldsymbol{C}$. Norm. Mod. Index, normalized modulation index; VEH, vehicle.

were significantly different from that in sham-vehicle mice for low-frequency $\gamma$ (Fig. 5B-D), but SMM-189 did not correct PAC abnormality for high $\gamma$ seen in the vehicletreated 50-psi mice.

\section{Effects of SMM-189 on neuronal activity in healthy, sham-treated mice}

Ten mice were treated with sham blasts and randomly assigned to receive daily SMM-189 $(n=5)$ or vehicle $(n=$ 5) injections for two weeks, i.e., the same treatment regimes as the blast-treated mTBI mice. Comparison of drug and vehicle-treated mice showed that in healthy mice SMM-189 treatment did not alter any of the electrophysiological measures we analyzed. LFP coherence within the CA1 and PFC was the same in drug and vehicle-treated mice (Fig. 6A,B), as were hippocampal SWR wave form, SWR-aligned mPFC LFP responses (Fig. $6 C, D$ ) and the SWR peak frequency and power (Fig. $6 E-H)$. The main findings are summarized in Table 1.

\section{Discussion}

We examined cortical and hippocampal oscillatory neuronal activity patterns in the MPFC and CA1 of awake, head-fixed mice to determine if mTBI produces abnormalities in these brain regions and thereby to determine if dysfunction in these structures contributes to the resulting cognitive and neuropsychiatric deficits. Previous studies have shown that $\mathrm{mTBI}$ in the closed-head, focal air blast mouse model used here causes diffuse axonal damage and neuron death, and a variety of sensory, motor, cognitive, and emotional deficits (the latter including fearfulness and depression), as also observed in MTBI patients (Heldt et al., 2014; Bu et al., 2016; Guley et al., 2016). In the present study, we observed several neurophysiological abnormalities in oscillatory activity linked to the role of mPFC and CA1 in cognition, mood and affect, including in coherence and PAC of oscillatory neuronal activity, mPFC responses to hippocampal SWRs, and the peak frequency of SWRs. Specifically, the coherence of oscillatory activity was increased across the $\delta$ to $\beta$ frequency range $(2-30 \mathrm{~Hz})$ after mTBI in the mPFC, but not in hippocampal CA1. PAC between $\theta$ phase and $\gamma$ amplitude was also significantly increased in the mPFC, but not in CA1 after mTBI.

Our electrophysiological recordings were all made on the left side of the brain, the side that was targeted by the 
A
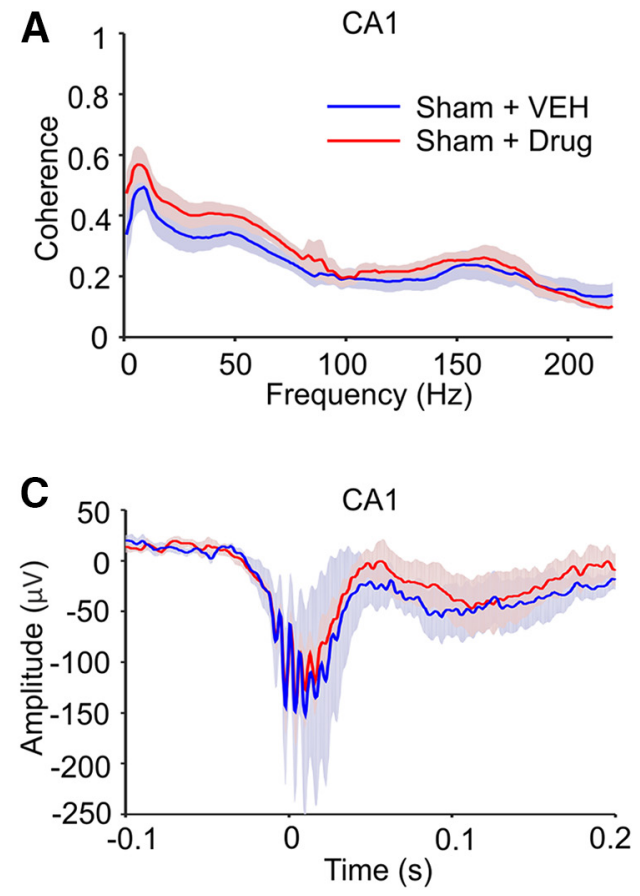
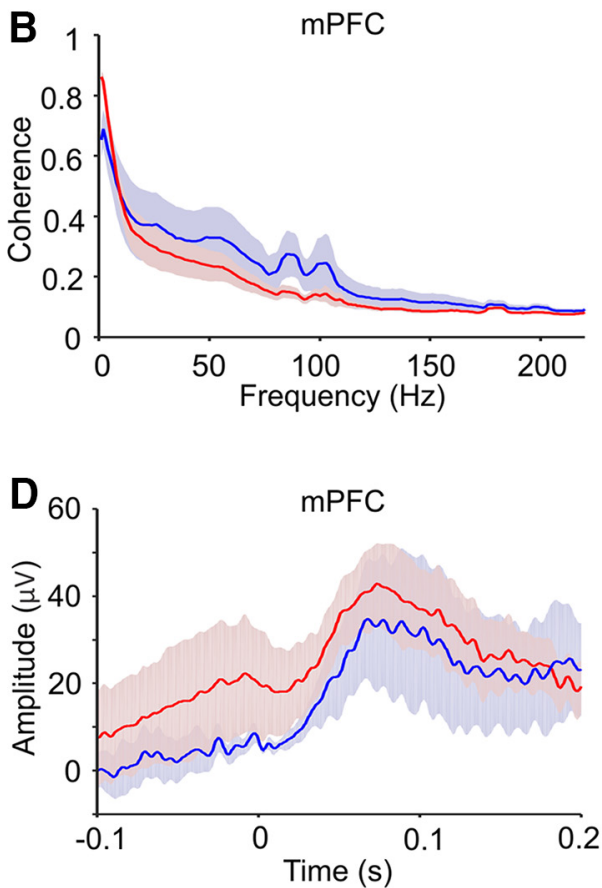
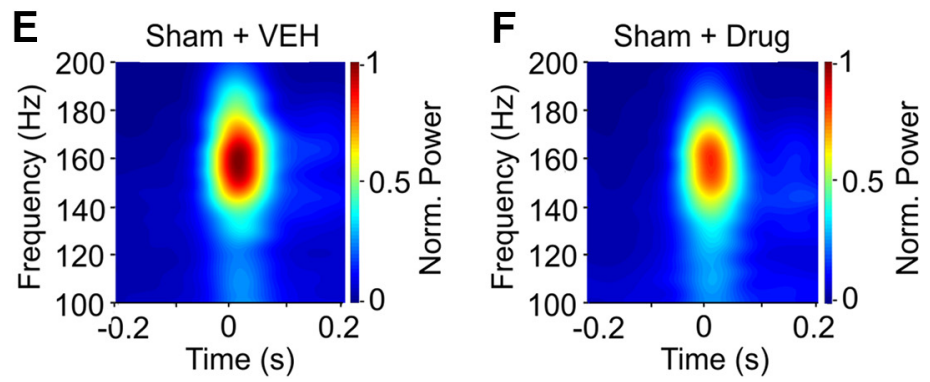

G

H

peak-freq

peak-freq power
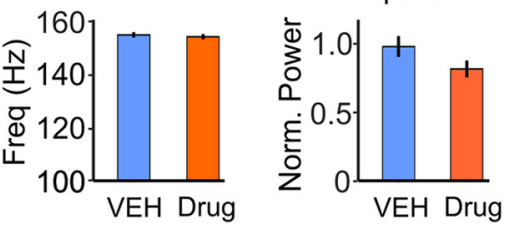

Figure 6. Effects of vehicle (VEH, blue traces) and SMM-189 (drug, red traces) treatment on neuronal activity in sham-treated control mice. $\boldsymbol{A}$, Coherence of LFP in hippocampal CA1 region (CA1) in drug and vehicle-treated sham mice. $\boldsymbol{B}$, Coherence of LFP in the mPFC. $\boldsymbol{C}$, Average SWR wave form in CA1 in drug and vehicle-treated mice. $\boldsymbol{D}$, Average LFP responses in the mPFC aligned with SWR onset in drug and vehicle-treated mice. $\boldsymbol{E}, \boldsymbol{F}$, Time-frequency mapping of SWR activity in CA1 in drug and vehicle-treated mice. Time 0 corresponds to SWR onset. Pseudocolors represent frequency power normalized to the maximum power (Norm. Power) within both groups. $\boldsymbol{G}, \boldsymbol{H}$, Quantitative representation and comparison of peak frequency $(\boldsymbol{G})$ and normalized peak power $(\boldsymbol{H})$ of SWR activity shown in panels $\boldsymbol{E}, \boldsymbol{F}$. Statistical comparison (one-way ANOVA) of all quantitative endpoints between drug versus vehicle-treated mice revealed no differences between the two groups in any of the measures.

blast. Previous studies have shown that neuron loss is restricted to the left side for the basolateral amygdala, whereas it is similar for the right and left sides of cerebral cortex and striatum (Bu et al., 2016). Further experimental work is needed to determine if electrophysiological abnormalities in MPFC and CA1 are similar on the contralateral side or less severe

The rescue of these electrophysiological abnormalities with SMM-189 treatment, which has been shown in previous studies to rescue mTBI behavioral deficits, is consistent with the interpretation that the abnormalities in oscillatory behavior in mPFC and CA1 may play a role in the behavioral deficits. SMM-189 is known to target CB2 receptors on microglia and causes a bias in microglial activation from the proinflammatory (M1) to the prohealing (M2) state (Presley et al., 2015). Thus, the most likely mechanism behind the rescue of electrophysiological def- icits we observed here is the rescue of neuron death and synapse loss by the modulatory effect of SMM-189 on neuroinflammatory responses. By contrast, SMM-189 treatment had no effect on any measures of neuronal activity in healthy, sham-treated mice, suggesting that the SMM-189 benefit in mTBI did not stem from some effect that proved compensatory for the mTBI abnormalities. The implications of these findings are considered in more detail below.

\section{Role of oscillatory activity in brain function}

Oscillations in LFPs represent the coordinated rhythmic activation of large populations of synaptic inputs to the neurons at the site of LFP recording (Buzsáki et al., 2012). This oscillatory activity influences the timing of neuronal activation within local ensembles of neurons, thus affect- 
Table 1. Summary of effects of SMM-189 on LFP and hippocampal SWR activity in mice with mTBI

\begin{tabular}{|c|c|c|c|c|c|c|c|c|c|}
\hline & \multicolumn{3}{|c|}{ CA1 } & \multicolumn{3}{|c|}{ mPFC } & \multicolumn{3}{|c|}{ S1/V1 } \\
\hline & Sham + drug & $m T B I+V E H$ & mTBI + drug & Sham + drug & mTBI + VEH & mTBI + drug & Sham + drug & mTBI + VEH & mTBI + drug \\
\hline $\begin{array}{l}\text { LFP power } \\
\text { spectrum }\end{array}$ & $\begin{array}{l}\text { Same as } \\
\text { sham + VEH }\end{array}$ & $\begin{array}{l}\text { Same as } \\
\text { sham + VEH }\end{array}$ & $\begin{array}{l}\text { Same as } \\
\text { sham + VEH }\end{array}$ & $\begin{array}{l}\text { Same as } \\
\text { sham + VEH }\end{array}$ & $\begin{array}{l}\text { Same as } \\
\text { sham + VEH }\end{array}$ & $\begin{array}{l}\text { Same as } \\
\text { sham + VEH }\end{array}$ & $\begin{array}{l}\text { Same as } \\
\text { sham + VEH }\end{array}$ & $\begin{array}{l}\text { Same as } \\
\text { sham + VEH }\end{array}$ & $\begin{array}{l}\text { Same as } \\
\text { sham + VEH }\end{array}$ \\
\hline $\begin{array}{l}\text { LFP coherence } \\
\text { within area }\end{array}$ & $\begin{array}{l}\text { Same as } \\
\text { sham + VEH }\end{array}$ & $\uparrow$ & $\begin{array}{l}\text { Same as } \\
\text { sham + VEH }\end{array}$ & $\begin{array}{l}\text { Same as } \\
\text { sham + VEH }\end{array}$ & $\begin{array}{l}\text { Same as } \\
\text { sham + VEH }\end{array}$ & $\begin{array}{l}\text { Same as } \\
\text { sham + VEH }\end{array}$ & $\begin{array}{l}\text { Same as } \\
\text { sham + VEH }\end{array}$ & $\uparrow$ & $\uparrow$ \\
\hline $\begin{array}{l}\text { LFP coherence } \\
\text { with CA1 }\end{array}$ & $\mathrm{N} / \mathrm{A}$ & N/A & $\mathrm{N} / \mathrm{A}$ & $\begin{array}{l}\text { Same as } \\
\text { sham + VEH }\end{array}$ & $\begin{array}{l}\text { Same as } \\
\text { sham + VEH }\end{array}$ & $\begin{array}{l}\text { Same as } \\
\text { sham + VEH }\end{array}$ & $\mathrm{N} / \mathrm{A}$ & $\mathrm{N} / \mathrm{A}$ & N/A \\
\hline $\begin{array}{l}\text { LFP coherence } \\
\text { with S1/V1 }\end{array}$ & N/A & N/A & N/A & $\begin{array}{l}\text { Same as } \\
\text { sham + VEH }\end{array}$ & $\begin{array}{l}\text { Same as } \\
\text { sham + VEH }\end{array}$ & $\begin{array}{l}\text { Same as } \\
\text { sham + VEH }\end{array}$ & $\mathrm{N} / \mathrm{A}$ & $\mathrm{N} / \mathrm{A}$ & N/A \\
\hline SWR frequency & $\begin{array}{l}\text { Same as } \\
\text { sham + VEH }\end{array}$ & $\downarrow$ & $\begin{array}{l}\text { Same as } \\
\text { sham + VEH }\end{array}$ & N/A & N/A & N/A & $\mathrm{N} / \mathrm{A}$ & $\mathrm{N} / \mathrm{A}$ & $\mathrm{N} / \mathrm{A}$ \\
\hline $\begin{array}{l}\text { SWR relative } \\
\text { frequency power }\end{array}$ & $\begin{array}{l}\text { Same as } \\
\text { sham + VEH }\end{array}$ & $\begin{array}{l}\text { Same as } \\
\text { sham + VEH }\end{array}$ & $\begin{array}{l}\text { Same as } \\
\text { sham + VEH }\end{array}$ & $\mathrm{N} / \mathrm{A}$ & $\mathrm{N} / \mathrm{A}$ & N/A & $\mathrm{N} / \mathrm{A}$ & N/A & $\mathrm{N} / \mathrm{A}$ \\
\hline $\begin{array}{l}\text { SWR-associated } \\
\text { LFP amplitude }\end{array}$ & $\begin{array}{l}\text { Same as } \\
\text { sham + VEH }\end{array}$ & $\begin{array}{l}\text { Same as } \\
\text { sham + VEH }\end{array}$ & $\uparrow$ & $\begin{array}{l}\text { Same as } \\
\text { sham + VEH }\end{array}$ & $\downarrow$ & $\begin{array}{l}\text { Same as } \\
\text { sham + VEH }\end{array}$ & $\mathrm{N} / \mathrm{A}$ & $\mathrm{N} / \mathrm{A}$ & $\mathrm{N} / \mathrm{A}$ \\
\hline$\theta-\gamma$ coupling & N/A & $\begin{array}{l}\text { Same as } \\
\quad \text { sham + VEH }\end{array}$ & $\begin{array}{l}\text { Same as } \\
\quad \text { sham + VEH }\end{array}$ & N/A & $\uparrow$ & $\begin{array}{l}\text { Same as } \\
\text { sham + VEH }\end{array}$ & N/A & $\mathrm{N} / \mathrm{A}$ & $\mathrm{N} / \mathrm{A}$ \\
\hline
\end{tabular}

CA1, hippocampal CA1 region; N/A, not applicable; VEH, vehicle; $\uparrow$, increase; $\downarrow$, decrease.

ing communication between each such ensemble and other neuronal populations to which it projects, for example in distant target regions. Coherence of oscillations within a given brain region also are of note, since the phase locking of activity within a region can affect the granularity of the output from that region. Consistent with its importance in neuronal communication, oscillatory neuronal activity, including dynamic changes in the coherence of oscillations (Fries, 2015) and PAC (Canolty et al., 2006; Tort et al., 2009), has been widely linked to cognitive brain functions, including attention (Fries et al., 2001; Laufs et al., 2003; Tallon-Baudry, 2004; Fries, 2015), perception (Engel et al., 2001; Tallon-Baudry, 2003), decision making (Gould et al., 2012; Wyart et al., 2012; Nácher et al., 2013), problem solving (Sheth et al., 2009), and memory (Marshall et al., 2006; Tort et al., 2009; Chauvette et al., 2012; Anderson et al., 2014). Abnormalities in these neuronal oscillatory patterns have been observed in a variety of brain disorders and are regarded as revealing neuronal dysfunction that underlies cognitive and emotional deficits, including in mTBI (Leon-Carrion et al., 2012; Haneef et al., 2013; Bailey et al., 2014; Dimitriadis et al., 2015). In particular, abnormalities in oscillatory activity in the mPFC have been strongly linked to depression and deficits in fear extinction, both in humans (López et al., 2014; Olbrich et al., 2014) and rodents (Milad and Quirk, 2002; Sierra-Mercado et al., 2006). With regard to the latter, Quirk and colleagues have shown that fear extinction is an active process requiring an intact and normally functioning $\mathrm{mPFC}$, and that fear perseveration ensues otherwise (Milad and Quirk, 2002). Additionally, studies in humans have linked the modulation of $\gamma$ oscillation power in the MPFC to fear extinction (Mueller et al.,
2014). Perseverance of fearful memories and depression are characteristic findings in patients suffering from mTBI (Kennedy et al., 2007; Bombardier et al., 2010; Miller, 2011a; Reiner et al., 2014), and could thus stem from mPFC dysfunction.

\section{Coherence abnormalities in our studies}

With these considerations, the abnormalities we observed in mPFC coherence following mTBI may be contributors to deficits in working memory in a spontaneous cross-maze alternation task (our unpublished observations), as well as to the depression and fearfulness reported with this model (Heldt et al., 2014). The reversal of both behavioral deficits (Reiner et al., 2014) and coherence abnormalities in multiple frequency ranges with SMM-189 further supports the view that the electrophysiological dysfunction in mPFC reflects functional changes that contribute to the cognitive and emotional deficits associated with mTBI.

The temporal coordination of the phases of oscillatory neuronal activity requires the integrity of axonal projections and of synaptic connections (Buzsáki et al., 2013). Diffuse, widespread axonal damage and neuron death are characteristic features of mTBI (Browne et al., 2011; Johnson et al., 2013; Lafrenaye et al., 2015; Bu et al., 2016) and may be key factors underlying the oscillatory abnormalities observed here. Although mTBI might be expected to result in a reduction of coherence strength if there is loss of network connectivity or synaptic inputs from other structures, we found a significant increase in coherence in the mPFC of mTBI mice across a lowfrequency range (1-30 Hz) covering $\delta, \theta, \alpha$, and $\beta$ bands, and in a high frequency range $(150-200 \mathrm{~Hz})$. It is unclear 
how mTBI would cause increased coherence. Coherence studies in rodent models of Parkinson's disease have shown that the loss of dopamine causes increases in cortico-striatal coherence (Sharott et al., 2005). Whether loss of dopaminergic neurons and/or their connections is responsible for increased mPFC coherence after mTBI in mice remains to be shown. Alternatively, or in addition, the loss of excitatory extrinsic inputs from other cortical regions or from thalamus may cause mPFC to default to heightened coherence driven by intrinsic connectivity.

\section{SWR abnormalities in our studies}

The hippocampal network generates characteristic SWR activity which has been shown to be critically involved in memory consolidation and memory retrieval in mice (Malvache et al., 2016; Nicole et al., 2016; van de Ven et al., 2016), rats (Jadhav et al., 2012; Singer et al., 2013; Pfeiffer and Foster, 2015; Maingret et al., 2016; Papale et al., 2016; O'Neill et al., 2017; Rothschild et al., 2017; Wu et al., 2017), and nonhuman primates (Logothetis et al., 2012; Ramirez-Villegas et al., 2015; Leonard and Hoffman, 2017). We found that mTBI caused a reduction in the average frequency of hippocampal SWRs and eliminated SWR-evoked responses in the mPFC. Given the crucial role of hippocampal SWRs and their transmission to the mPFC for long-term memory functions (Wierzynski et al., 2009), deficits in SWR frequency and SWR-evoked responses in the MPFC may be causally related to memory deficits associated with mTBI (Lundin et al., 2006; Sim et al., 2012).

\section{PAC abnormalities in our studies}

We also found that coupling between the phase of $\theta$ band oscillations and the amplitude of $\gamma$ oscillations in the mPFC was increased in mTBI mice. Treatment of mTBI mice with SMM-189 partially rescued this PAC abnormality in the lower $\gamma$ frequency range $(30-55 \mathrm{~Hz})$ but not in the high $\gamma$ frequency range $(55-100 \mathrm{~Hz})$. It has been suggested that PAC coordinates neuronal communication within and across brain regions related to information processing (Canolty and Knight, 2010). The strength of PAC within the mPFC correlates with correct versus incorrect decisions in a spatial working memory task in rats (Li et al., 2012), supporting the link between PAC and cognitive processes. Currently, however, it is uncertain how the strength of PAC is controlled and we can thus only speculate how $\mathrm{mTBI}$ may increase PAC. One possibility is that reduced axonal connectivity after TBI decreases the influence of some modulatory input that normally maintains PAC within a specific range. It is also likely that diffuse neuronal death from mTBI results in changes to regional balances of excitatory and inhibitory synaptic activity, as this balance is known to underlie the amplitude and frequency of $\gamma$ oscillations (Economo and White, 2012; Brunel and Wang, 2013). Whether and to what degree these or other mechanisms contribute to the PAC abnormality remains to be determined.

\section{Mild TBI: mechanisms of injury and rescue with SMM-189}

Mild TBI involves both primary damage from the compressive, tensile and shear forces during the closed-head injury and secondary damage due to neuroinflammatory responses set in motion by the trauma (Joseph et al., 2015; Lafrenaye et al., 2015; Werner and Stevens, 2015; Loane and Kumar, 2016). CB2 receptors are primarily expressed by microglia in the brain after mTBI (Elliott et al., 2011; Donat et al., 2014; Lopez-Rodriguez et al., 2016). We have previously shown that the CB2 receptor inverse agonist SMM-189 mitigates behavioral deficits and neuropathology caused by mTBI (Reiner et al., 2014). More recently we reported that SMM-189 significantly rescues $\mathrm{mTBI}$ induced neuron death in the neocortex, basal ganglia and the basolateral amygdala (Bu et al., 2016). These findings, together with the well-known involvement of microglia in neuron death and the pruning and plasticity of synapses (Brown and Vilalta, 2015; Hong et al., 2016; Loane and Kumar, 2016), provide a possible mechanism of benefit for a drug that acts predominantly on microglia to rescue the currently observed mTBIrelated electrophysiological deficits. Coherence and PAC of oscillatory neuronal activity reflect functional connectivity patterns in larger neuronal networks (Antonakakis et al., 2015). Thus, a deficit in network connectivity through neuron death and/or synapse loss following mTBI would inevitably lead to abnormalities in coherence and functional connectivity. Thus, it is likely that the ability of SMM-189 to rescue the electrophysiological abnormalities reported here is ultimately based on the prevention or reduction of neuron death and synapse loss. Which activity patterns are rescued and which are not, and in which specific brain regions rescue occurs, is likely to depend on the severity of damage sustained in a specific area and possible differences between types of neurons in susceptibility to $\mathrm{mTBI}$-related cell death.

Interestingly, SMM-189 treatment did not rescue the coherence deficit in S1/N1 following mTBI. Other than a general loss of network connectivity, we currently have no definitive understanding of the neuropathology and/or cellular changes underlying the current coherence abnormalities. SMM-189 treatment rescues neuron death in the neocortex after mTBI, preventing about half of an overall $20 \%$ loss of cortical neurons (Bu et al., 2016), but whether the benefit of SMM-189 is less for the S1/N1 region than for other parts of the neocortex or whether damage in $\mathrm{S} 1 / \mathrm{V} 1$ is more severe than in other areas has yet been determined.

A therapeutic potential of CB2 receptor inverse agonists has been proposed for several years (Lunn et al., 2008), but studies of their benefits for brain activity and behavior in neurodegenerative diseases have been scant. The SMM-189 structural class of tri-aryl compounds shows good blood-brain barrier penetration (Fujinaga et al., 2010) and Presley et al. (2015) have shown that SMM-189 binds selectively to the CB2 receptor. Further, SMM-189 has been shown to convert human microglia from the proinflammatory M1 phenotype to the prohealing M2 phenotype (Reiner et al., 2014; Presley et al., 2015), 
suggesting that the beneficial effects of SMM-189 after $\mathrm{mTBl}$ are linked to the alteration of microglial activation state so that microglia act to minimize loss and increase rescue. The previously reported rescue of axonal damage (Reiner et al., 2014) and the rescue of neuron death (Bu et al., 2016) in mTBI mice by SMM-189 treatment are likely to be key factors in the rescue of the diverse mTBIrelated electrophysiological deficits we observed with SMM-189. Although the enrichment of microglia in CB2 receptors compared to other brain cell types (Benito et al., 2003; Stella, 2010; Baek et al., 2013) suggests them to be the primary site of action for SMM-189 benefit, we cannot rule out the possibility that SMM-189 benefit involved a neuronal action, as some neuronal localization of CB2 receptors has been reported (Stempel et al., 2016). Nonetheless, as SMM-189 treatment was limited to two weeks after TBI and thus had ended several weeks before our recordings, it is clear the SMM-189 benefit is enduring and not merely palliative in nature.

\section{Summary}

In summary, our findings suggest that mTBI impairs the functioning of mPFC and CA1, structures that are widely implicated in memory, mood and affect. Our studies show that post-mTBI abnormalities in MPFC and CA1 involve neuronal mechanisms implicated in the precise spatial and temporal coordination of neuronal activity within and between brain structures. Our observations were made in awake, head-fixed mice, which most closely corresponds to resting-state recordings in human studies. Restingstate measurements reliably indicate abnormalities in brain function, as shown by studies on such illnesses as Alzheimer's disease, schizophrenia and autism (Pollonini et al., 2010; Hsiao et al., 2013; Kam et al., 2013) or normal aging (Salami et al., 2014). Thus, resting-state measures of $\gamma$ power modulation, for example, could be explored for the development of EEG-based diagnostic tools to determine the severity, progression, and/or treatment success in $\mathrm{mTBI}$ patients. Although the various electrophysiological abnormalities we observed in the resting-state have been linked to memory, mood and affect, studies in awake behaving mice will be needed to determine if behavior-related activity patterns and associated behaviors are similarly rescued by SMM-189 treatment. Finally, our current results reinforce prior findings on the significant benefits of SMM-189 treatment for $\mathrm{mTBI}$ in mice (Reiner et al., 2014; Bu et al., 2016). Of note, we found that SMM-189 does not alter the brain activity in healthy, sham-treated mice. Our findings, combined with those earlier results suggest that drugs like SMM-189, which quell the adverse effects of M1 microglial activation and promote their beneficial M2 phenotype via a targeting of microglial CB2 receptors (Presley et al., 2015), represent a promising treatment strategy for $\mathrm{mTBI}$.

\section{References}

Anderson DE, Serences JT, Vogel EK, Awh E (2014) Induced alpha rhythms track the content and quality of visual working memory representations with high temporal precision. J Neurosci 34:75877599. CrossRef Medline
Antonakakis $\mathrm{M}$, Dimitriadis $\mathrm{SI}$, Zervakis $\mathrm{M}$, Rezaie R, BabajaniFeremi A, Micheloyannis S, Zouridakis G, Papanicolaou AC (2015) Comparison of brain connectivity models using cross-frequency coupling and attack strategies. Conf Proc IEEE Eng Med Biol Soc 2015:7426-7429.

Baek JH, Darlington CL, Smith PF, Ashton JC (2013) Antibody testing for brain immunohistochemistry: brain immunolabeling for the cannabinoid $\mathrm{CB}_{2}$ receptor. J Neurosci Methods 216:87-95. CrossRef Medline

Bahner F, Demanuele C, Schweiger J, Gerchen MF, Zamoscik V, Ueltzhöffer K, Hahn T, Meyer P, Flor H, Durstewitz D, Tost $H$, Kirsch P, Plichta MM, Meyer-Lindenberg A (2015) Hippocampaldorsolateral prefrontal coupling as a species-conserved cognitive mechanism: a human translational imaging study. Neuropsychopharmacology 40:1674-1681. CrossRef Medline

Bailey NW, Segrave RA, Hoy KE, Maller JJ, Fitzgerald PB (2014) Impaired upper alpha synchronisation during working memory retention in depression and depression following traumatic brain injury. Biol Psychol 99:115-124. CrossRef Medline

Bazarian JJ, Donnelly K, Peterson DR, Warner GC, Zhu T, Zhong J (2013) The relation between posttraumatic stress disorder and mild traumatic brain injury acquired during Operations Enduring Freedom and Iraqi Freedom. J Head Trauma Rehabil 28:1-12. CrossRef Medline

Benito C, Núñez E, Tolón RM, Carrier EJ, Rábano A, Hillard CJ, Romero J (2003) Cannabinoid CB2 receptors and fatty acid amide hydrolase are selectively overexpressed in neuritic plaqueassociated glia in Alzheimer's disease brains. J Neurosci 23: 11136-11141. Medline

Bocchio M, Capogna M (2014) Oscillatory substrates of fear and safety. Neuron 83:753-755. CrossRef Medline

Bombardier CH, Fann JR, Temkin NR, Esselman PC, Barber J, Dikmen SS (2010) Rates of major depressive disorder and clinical outcomes following traumatic brain injury. JAMA 303:1938-1945. CrossRef

Brown GC, Vilalta A (2015) How microglia kill neurons. Brain Res 1628:288-297. CrossRef Medline

Browne KD, Chen XH, Meaney DF, Smith DH (2011) Mild traumatic brain injury and diffuse axonal injury in swine. J Neurotrauma 28:1747-1755. CrossRef Medline

Brunel N, Wang XJ (2013) What determines the frequency of fast network oscillations with irregular neural discharges? I. Synaptic dynamics and excitation-inhibition balance. J Neurophysiol 90: 415-430. CrossRef

Bruns A, Eckhorn R (2004) Task-related coupling from high- to low-frequency signals among visual cortical areas in human subdural recordings. Int J Psychophysiol 51:97-116. Medline

Bryant JL, Roy S, Heck DH (2009) A technique for stereotaxic recordings of neuronal activity in awake, head-restrained mice. $J$ Neurosci Methods 178:75. CrossRef Medline

Bryant RA, O'Donnell ML, Creamer M, McFarlane AC, Clark CR, Silove D (2010) The psychiatric sequelae of traumatic injury. Am J Psychiatry 167:312-320. CrossRef Medline

Bu W, Ren H, Deng YP, Del Mar N, Guley NG, Gao Y, Honig MG, Heldt SA, Moore BM, Reiner A (2015) Neurons are lost in brain regions controlling movement and fear after mild TBI and rescued by a CB2 receptor inverse agonist. Soc Neurosci Abstract 309.25.

Bu W, Ren H, Deng Y, Del Mar N, Guley NG, Moore BM, Honig MG, Reiner A (2016) Mild traumatic brain injury produces neuron loss that can be rescued by modulating microglial activation using a CB2 receptor inverse agonist. Front Neurosci 10:449. CrossRef

Buzsáki G (2015) Hippocampal sharp wave-ripple: a cognitive biomarker for episodic memory and planning. Hippocampus 25: 1073-1188. CrossRef

Buzsáki G, Anastassiou CA, Koch C (2012) The origin of extracellular fields and currents - EEG, ECoG, LFP and spikes. Nat Rev Neurosci 13:407-420. CrossRef Medline

Buzsáki G, Logothetis N, Singer W (2013) Scaling brain size, keeping timing: evolutionary preservation of brain rhythms. Neuron 80:751764. CrossRef Medline 
Canolty RT, Knight RT (2010) The functional role of cross-frequency coupling. Trends Cogn Sci 14:506-515. CrossRef Medline

Canolty RT, Edwards E, Dalal SS, Soltani M, Nagarajan SS, Kirsch HE, Berger MS, Barbaro NM, Knight RT (2006) High gamma power is phase-locked to theta oscillations in human neocortex. Science 313:1626-1628. CrossRef Medline

Chauvette S, Seigneur J, Timofeev I (2012) Sleep oscillations in the thalamocortical system induce long-term neuronal plasticity. Neuron 75:1105-1113. CrossRef Medline

Covington HE 3rd, Lobo MK, Maze I, Vialou V, Hyman JM, Zaman S, LaPlant Q, Mouzon E, Ghose S, Tamminga CA, Neve RL, Deisseroth K, Nestler EJ (2010) Antidepressant effect of optogenetic stimulation of the medial prefrontal cortex. J Neurosci 30:1608216090. CrossRef

Dimitriadis SI, Zouridakis G, Rezaie R, Babajani-Feremi A, Papanicolaou AC (2015) Functional connectivity changes detected with magnetoencephalography after mild traumatic brain disorders. Neuroimage Clin 9:519-531.

Donat CK, Fischer F, Walter B, Deuther-Conrad W, Brodhun M, Bauer R, Brust P (2014) Early increase of cannabinoid receptor density after experimental traumatic brain injury in the newborn piglet. Acta Neurobiol Exp (Wars) 74:197-210. Medline

Economo MN, White JA (2012) Membrane properties and the balance between excitation and inhibition control gamma-frequency oscillations arising from feedback inhibition. PLoS Comput Biol 8:e1002354. CrossRef Medline

Elliott MB, Tuma RF, Amenta PS, Barbe MF, Jallo JI (2011) Acute effects of a selective cannabinoid-2 receptor agonist on neuroinflammation in a model of traumatic brain injury. J Neurotrauma 28:973-981. CrossRef

Engel AK, Fries P, Singer W (2001) Dynamic predictions: oscillations and synchrony in top-down processing. Nat Rev Neurosci 2:704716. CrossRef Medline

Fries P (2015) Rhythms for cognition: communication through coherence. Neuron 88:220-235. CrossRef Medline

Fries P, Reynolds JH, Rorie AE, Desimone R (2001) Modulation of oscillatory neuronal synchronization by selective visual attention. Science 291:1560-1563. CrossRef Medline

Fujinaga M, Kumata K, Yanamoto K, Kawamura K, Yamasaki T, Yui J, Hatori A, Ogawa M, Yoshida Y, Nengaki N, Maeda J, Zhang MR (2010) Radiosynthesis of novel carbon-11-labeled triaryl ligands for cannabinoid-type 2 receptor. Bioorg Med Chem Lett 20:15651568. CrossRef Medline

Gould IC, Nobre AC, Wyart V, Rushworth MF (2012) Effects of decision variables and intraparietal stimulation on sensorimotor oscillatory activity in the human brain. J Neurosci 32:1380513818. CrossRef

Guley NG, Rogers J, Del Mar N, Deng Y, Islam RM, D'Surney L, Ferrell J, Deng B, Hines-Beard J, Bu W, Ren H, Elberger AJ, Marchetta JG, Rex TS, Honig MG, Reiner A (2016) A novel closedhead model of mild traumatic brain injury using focal primary overpressure blast to the cranium in mice. J Neurotrauma 33:403422. CrossRef

Haneef Z, Levin HS, Frost JD Jr, Mizrahi EM (2013) Electroencephalography and quantitative electroencephalography in mild traumatic brain injury. J Neurotrauma 30:653-656. CrossRef Medline

Heldt SA, Elberger AJ, Deng Y, Guley NH, Del Mar N, Rogers J, Choi GW, Ferrell J, Rex TS, Honig MG, Reiner A (2014) A novel closedhead model of mild traumatic brain injury caused by primary overpressure blast to the cranium produces sustained emotional deficits in mice. Front Neurol 5:2. CrossRef Medline

Hong S, Dissing-Olesen L, Stevens B (2016) New insights on the role of microglia in synaptic pruning in health and disease. Curr Opin Neurobiol 36:128-134. CrossRef Medline

Hsiao FJ, Wang YJ, Yan SH, Chen WT, Lin YY (2013) Altered oscillation and synchronization of default-mode network activity in mild Alzheimer's disease compared to mild cognitive impairment: an electrophysiological study. PLoS One 8:e68792. CrossRef Medline
Ito J, Maldonado P, Grün S (2013) Cross-frequency interaction of the eye-movement related LFP signals in V1 of freely viewing monkeys. Front Syst Neurosci 7:1. CrossRef Medline

Jadhav SP, Kemere C, German PW, Frank LM (2012) Awake hippocampal sharp-wave ripples support spatial memory. Science 336:1454-1458. CrossRef Medline

Johnson VE, Stewart W, Smith DH (2013) Axonal pathology in traumatic brain injury. Exp Neurol 246:35-43. CrossRef Medline

Joseph B, Haider A, Rhee P (2015) Traumatic brain injury advancements. Curr Opin Crit Care 21:506-511. CrossRef Medline

Kam JW, Bolbecker AR, O'Donnell BF, Hetrick WP, Brenner CA (2013) Resting state EEG power and coherence abnormalities in bipolar disorder and schizophrenia. J Psychiatr Res 47:18931901. CrossRef Medline

Kennedy JE, Jaffee MS, Leskin GA, Stokes JW, Leal FO, Fitzpatrick PJ (2007) Posttraumatic stress disorder and posttraumatic stress disorder-like symptoms and mild traumatic brain injury. J Rehabil Res Dev 44:895-920. Medline

Lafrenaye AD, Todani M, Walker SA, Povlishock JT (2015) Microglia processes associate with diffusely injured axons following mild traumatic brain injury in the micro pig. J Neuroinflammation 12: 186. CrossRef Medline

Laufs H, Krakow K, Sterzer P, Eger E, Beyerle A, Salek-Haddadi A, Kleinschmidt A (2003) Electroencephalographic signatures of attentional and cognitive default modes in spontaneous brain activity fluctuations at rest. Proc Natl Acad Sci USA 100:11053-11058. CrossRef Medline

Leon-Carrion J, Leon-Dominguez U, Pollonini L, Wu MH, Frye RE, Dominguez-Morales MR, Zouridakis G (2012) Synchronization between the anterior and posterior cortex determines consciousness level in patients with traumatic brain injury (TBI). Brain Res 1476: 22-30. CrossRef Medline

Leonard TK, Hoffman KL (2017) Sharp-wave ripples in primates are enhanced near remembered visual objects. Curr Biol 27:257-262. CrossRef Medline

Li S, Bai W, Liu T, Yi H, Tian X (2012) Increases of theta-low gamma coupling in rat medial prefrontal cortex during working memory task. Brain Res Bull 89:115-123. CrossRef Medline

Lisman JE, Jensen O (2013) The $\theta-\gamma$ neural code. Neuron 77:10021016. CrossRef Medline

Loane DJ, Kumar A (2016) Microglia in the TBI brain: the good, the bad, and the dysregulated. Exp Neurol 275:316-327. CrossRef Medline

Logothetis NK, Eschenko O, Murayama Y, Augath M, Steudel T, Evrard HC, Besserve M, Oeltermann A (2012) Hippocampalcortical interaction during periods of subcortical silence. Nature 491:547-553. CrossRef Medline

López ME, Bruña R, Aurtenetxe S, Pineda-Pardo JA, Marcos A, Arrazola J, Reinoso Al, Montejo P, Bajo R, Maestú F (2014) Alphaband hypersynchronization in progressive mild cognitive impairment: a magnetoencephalography study. J Neurosci 34:1455114559. CrossRef Medline

Lopez-Rodriguez AB, Mela V, Acaz-Fonseca E, Garcia-Segura LM, Viveros MP (2016) CB2 cannabinoid receptor is involved in the anti-inflammatory effects of leptin in a model of traumatic brain injury. Exp Neurol 279:274-282. CrossRef

Lundin A, de Boussard C, Edman G, Borg J (2006) Symptoms and disability until 3 months after mild TBI. Brain Inj 20:799-806. CrossRef Medline

Lunn CA, Reich EP, Fine JS, Lavey B, Kozlowski JA, Hipkin RW, Lundell DJ, Bober $L$ (2008) Biology and therapeutic potential of cannabinoid CB2 receptor inverse agonists. Br J Pharmacol 153: 226-239. CrossRef Medline

Maingret N, Girardeau G, Todorova R, Goutierre M, Zugaro M (2016) Hippocampo-cortical coupling mediates memory consolidation during sleep. Nat Neurosci 19:959-964. CrossRef

Malojcic B, Mubrin Z, Coric B, Susnic M, Spilich GJ (2008) Consequences of mild traumatic brain injury on information processing assessed with attention and short-term memory tasks. J Neurotrauma 25:30-37. CrossRef Medline 
Malvache A, Reichinnek S, Villette V, Haimerl C, Cossart R (2016) Awake hippocampal reactivations project onto orthogonal neuronal assemblies. Science 353:1280-1283. CrossRef Medline

Maroun M (2013) Medial prefrontal cortex: multiple roles in fear and extinction. Neuroscientist 19:370-383.

Marshall L, Helgadóttir H, Mölle M, Born J (2006) Boosting slow oscillations during sleep potentiates memory. Nature 444:610613. CrossRef Medline

Milad MR, Quirk GJ (2002) Neurons in medial prefrontal cortex signal memory for fear extinction. Nature 420:70-74. CrossRef Medline

Miller G (2011a) The invisible wounds of war. Healing the brain, healing the mind. Science 333:514-517. CrossRef Medline

Miller G (2011b) Neuropathology. A battle no soldier wants to fight. Science 333:517-519. CrossRef Medline

Mohajerani MH, Chan AW, Mohsenvand M, LeDue J, Liu R, McVea DA, Boyd JD, Wang YT, Reimers M, Murphy TH (2013) Spontaneous cortical activity alternates between motifs defined by regional axonal projections. Nat Neurosci 16:1426-1435. CrossRef Medline

Mueller EM, Panitz C, Hermann C, Pizzagalli DA (2014) Prefrontal oscillations during recall of conditioned and extinguished fear in humans. J Neurosci 34:7059-7066. CrossRef Medline

Nácher V, Ledberg A, Deco G, Romo R (2013) Coherent delta-band oscillations between cortical areas correlate with decision making. Proc Natl Acad Sci USA 110:15085-15090. CrossRef Medline

Nicole O, Hadzibegovic S, Gajda J, Bontempi B, Bem T, Meyrand P (2016) Soluble amyloid beta oligomers block the learning-induced increase in hippocampal sharp wave-ripple rate and impair spatial memory formation. Sci Rep 6:22728. CrossRef Medline

Niogi SN, Mukherjee P, Ghajar J, Johnson CE, Kolster R, Lee H, Suh M, Zimmerman RD, Manley GT, McCandliss BD (2008) Structural dissociation of attentional control and memory in adults with and without mild traumatic brain injury. Brain 131:3209-3221. CrossRef Medline

O'Neill J, Boccara CN, Stella F, Schoenenberger P, Csicsvari J (2017) Superficial layers of the medial entorhinal cortex replay independently of the hippocampus. Science 355:184-188.

Olbrich S, Tränkner A, Chittka T, Hegerl U, Schönknecht P (2014) Functional connectivity in major depression: increased phase synchronization between frontal cortical EEG-source estimates. Psychiatry Res 222:91-99. CrossRef Medline

Onslow AC, Bogacz R, Jones MW (2011) Quantifying phaseamplitude coupling in neuronal network oscillations. Prog Biophys Mol Biol 105:49-57. CrossRef Medline

Oostenveld R, Fries P, Maris E, Schoffelen JM (2011) FieldTrip: open source software for advanced analysis of MEG, EEG, and invasive electrophysiological data. Comput Intell Neurosci 2011:156869. CrossRef Medline

Osipova D, Hermes D, Jensen O (2008) Gamma power is phaselocked to posterior alpha activity. PLoS One 3:e3990. CrossRef Medline

Papale AE, Zielinski MC, Frank LM, Jadhav SP, Redish AD (2016) Interplay between hippocampal sharp-wave-ripple events and vicarious trial and error behaviors in decision making. Neuron 92: 975-982. CrossRef Medline

Paxinos G, Franklin KBJ (2001) The mouse brain in stereotaxic coordinates. San Diego: Academic Press.

Pfeiffer BE, Foster DJ (2015) Autoassociative dynamics in the generation of sequences of hippocampal place cells. Science 349: 180-183. CrossRef Medline

Pollonini L, Patidar U, Situ N, Rezaie R, Papanicolaou AC, Zouridakis G (2010) Functional connectivity networks in the autistic and healthy brain assessed using Granger causality. Conference proceedings of the Annual International Conference of the IEEE Engineering in Medicine and Biology Society. Conf Proc IEEE Eng Med Biol Soc 2010:1730-1733.

Popa D, Duvarci S, Popescu AT, Léna C, Paré D (2010) Coherent amygdalocortical theta promotes fear memory consolidation during paradoxical sleep. Proc Natl Acad Sci USA 107:6516-6519. CrossRef Medline
Presley C, Abidi A, Suryawanshi S, Mustafa S, Meibohm B, Moore BM (2015) Preclinical evaluation of SMM-189, a cannabinoid receptor 2-specific inverse agonist. Pharmacol Res Perspect 3:e00159. CrossRef Medline

Ramirez-Villegas JF, Logothetis NK, Besserve M (2015) Diversity of sharp-wave-ripple LFP signatures reveals differentiated brainwide dynamical events. Proc Natl Acad Sci USA 112:E6379E6387. CrossRef Medline

Rauch SL, Shin LM, Phelps EA (2006) Neurocircuitry models of posttraumatic stress disorder and extinction: human neuroimaging research-past, present, and future. Biol Psychiatry 60:376-382. CrossRef Medline

Reiner A, Heldt SA, Presley CS, Guley NH, Elberger AJ, Deng Y, D'Surney L, Rogers JT, Ferrell J, Bu W, Del Mar N, Honig MG, Gurley SN, Moore BM 2nd (2014) Motor, visual and emotional deficits in mice after closed-head mild traumatic brain injury are alleviated by the novel CB2 inverse agonist SMM-189. Int J Mol Sci 16:758-787. CrossRef

Rothschild G, Eban E, Frank LM (2017) A cortical-hippocampalcortical loop of information processing during memory consolidation. Nat Neurosci 20:251-259. CrossRef Medline

Roux F, Uhlhaas PJ (2014) Working memory and neural oscillations: $\alpha-\gamma$ versus $\theta-\gamma$ codes for distinct WM information? Trends Cogn Sci 18:16-25. CrossRef Medline

Russo SJ, Nestler EJ (2013) The brain reward circuitry in mood disorders. Nat Rev Neurosci 14:609-625. CrossRef Medline

Salami A, Pudas S, Nyberg L (2014) Elevated hippocampal restingstate connectivity underlies deficient neurocognitive function in aging. Proc Natl Acad Sci USA 111:17654-17659.

Schlingloff D, Káli S, Freund TF, Hájos N, Gulyás Al (2014) Mechanisms of sharp wave initiation and ripple generation. J Neurosci 34:11385-11398. CrossRef Medline

Sharott A, Magill PJ, Harnack D, Kupsch A, Meissner W, Brown P (2005) Dopamine depletion increases the power and coherence of beta-oscillations in the cerebral cortex and subthalamic nucleus of the awake rat. Eur J Neurosci 21:1413-1422. CrossRef Medline

Sheth BR, Sandkühler S, Bhattacharya J (2009) Posterior beta and anterior gamma oscillations predict cognitive insight. J Cogn Neurosci 21:1269-1279. CrossRef Medline

Sierra-Mercado D Jr, Corcoran KA, Lebrón-Milad K, Quirk GJ (2006) Inactivation of the ventromedial prefrontal cortex reduces expression of conditioned fear and impairs subsequent recall of extinction. Eur J Neurosci 24:1751-1758. CrossRef

Sigurdsson T, Duvarci S (2016) Hippocampal-prefrontal interactions in cognition, behavior and psychiatric disease. Front Syst Neurosci 9:190. CrossRef Medline

Sim A, Terryberry-Spohr L, Wilson KR (2012) Prolonged recovery of memory functioning after mild traumatic brain injury in adolescent athletes. J Neuroscurgery 116:511-516.

Singer AC, Carr MF, Karlsson MP, Frank LM (2013) Hippocampal SWR activity predicts correct decisions during the initial learning of an alternation task. Neuron 77:1163-1173. CrossRef Medline

Spellman T, Rigotti M, Ahmari SE, Fusi S, Gogos JA, Gordon JA (2015) Hippocampal-prefrontal input supports spatial encoding in working memory. Nature 522:309-314. CrossRef Medline

Stella N (2010) Cannabinoid and cannabinoid-like receptors in microglia, astrocytes, and astrocytomas. Glia 58:1017-1030. CrossRef Medline

Stempel AV, Stumpf A, Zhang HY, Özdoğan T, Pannasch U, Theis AK, Otte DM, Wojtalla A, Rácz I, Ponomarenko A, Xi ZX, Zimmer A, Schmitz D (2016) Cannabinoid type 2 receptors mediate a cell type-specific plasticity in the hippocampus. Neuron 90:795-809. CrossRef Medline

Sullivan D, Csicsvari J, Mizuseki K, Montgomery S, Diba K, Buzsáki G (2011) Relationships between hippocampal sharp waves, ripples, and fast gamma oscillation: influence of dentate and entorhinal cortical activity. J Neurosci 31:8605-8616. CrossRef Medline

Tallon-Baudry C (2003) Oscillatory synchrony and human visual cognition. J Physiol Paris 97:355-363. CrossRef Medline 
Tallon-Baudry C (2004) Attention and awareness in synchrony. Trends Cogn Sci 8:523-525. CrossRef Medline

Tort AB, Komorowski RW, Manns JR, Kopell NJ, Eichenbaum H (2009) Theta-gamma coupling increases during the learning of item-context associations. Proc Natl Acad Sci USA 106:2094220947. CrossRef Medline

Vaidya SP, Johnston D (2013) Temporal synchrony and gamma-totheta power conversion in the dendrites of CA1 pyramidal neurons. Nat Neurosci 16:1812-1820. CrossRef Medline

van de Ven GM, Trouche S, McNamara CG, Allen K, Dupret D (2016) Hippocampal offline reactivation consolidates recently formed cell assembly patterns during sharp wave-ripples. Neuron 92:968974. CrossRef Medline

Varotto G, Fazio P, Rossi Sebastiano D, Duran D, D'Incerti L, Parati E, Sattin D, Leonardi M, Franceschetti S, Panzica F (2014) Altered resting state effective connectivity in long-standing vegetative state patients: an EEG study. Clin Neurophysiol 125:63-68. CrossRef

Weinberger S (2011) Bombs' hidden impact: the brain war. Nature 477:390-393. CrossRef Medline
Werner JK, Stevens RD (2015) Traumatic brain injury: recent advances in plasticity and regeneration. Curr Opin Neurol 28:565573. CrossRef Medline

Wierzynski CM, Lubenov EV, Gu M, Siapas AG (2009) Statedependent spike-timing relationships between hippocampal and prefrontal circuits during sleep. Neuron 61:587-596. CrossRef Medline

Wu CT, Haggerty D, Kemere C, Ji D (2017) Hippocampal awake replay in fear memory retrieval. Nat Neurosci 20:571-580. CrossRef Medline

Wyart V, de Gardelle V, Scholl J, Summerfield C (2012) Rhythmic fluctuations in evidence accumulation during decision making in the human brain. Neuron 76:847-858. CrossRef Medline

Zelikowsky M, Hersman S, Chawla MK, Barnes CA, Fanselow MS (2014) Neuronal ensembles in amygdala, hippocampus, and prefrontal cortex track differential components of contextual fear. $J$ Neurosci 34:8462-8466. CrossRef 